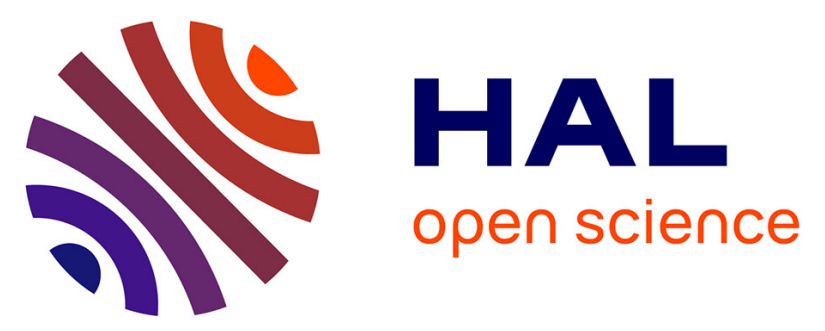

\title{
Fifty-year dynamics of the Lena River islands (Russia): Spatio-temporal pattern of large periglacial anabranching river and influence of climate change
}

Emmanuèle Gautier, Thomas Dépret, Julien Cavero, François Costard, Clément Virmoux, Alexander Fedorov, Pavel Konstantinov, Maël Jammet, Daniel Brunstein

\section{To cite this version:}

Emmanuèle Gautier, Thomas Dépret, Julien Cavero, François Costard, Clément Virmoux, et al.. Fifty-year dynamics of the Lena River islands (Russia): Spatio-temporal pattern of large periglacial anabranching river and influence of climate change. Science of the Total Environment, 2021, 783, pp.147020. 10.1016/j.scitotenv.2021.147020 . hal-03353117

\section{HAL Id: hal-03353117 https://hal.science/hal-03353117}

Submitted on 21 Oct 2021

HAL is a multi-disciplinary open access archive for the deposit and dissemination of scientific research documents, whether they are published or not. The documents may come from teaching and research institutions in France or abroad, or from public or private research centers.
L'archive ouverte pluridisciplinaire HAL, est destinée au dépôt et à la diffusion de documents scientifiques de niveau recherche, publiés ou non, émanant des établissements d'enseignement et de recherche français ou étrangers, des laboratoires publics ou privés. 


\section{Fifty-year dynamics of the Lena River islands (Russia): spatio-temporal pattern of large periglacial anabranching river and influence of climate change}

Emmanuèle GAUTIER, Université Paris 1 Panthéon-Sorbonne, Laboratoire de Géographie Physique, CNRS UMR8591, 1 Place Aristide Briand 92195 Meudon - France

Thomas DEPRET, Laboratoire de Géographie Physique, CNRS UMR8591, 1 Place Aristide Briand 92195 Meudon France, France

Julien CAVERO, Laboratoire de Géographie Physique, CNRS UMR8591, 1 Place Aristide Briand 92195 Meudon France, France

François COSTARD, Laboratoire GEOPS-Geosciences Paris Sud, CNRS UMR 8148, Université Paris-Saclay, Université Paris Sud, Bat.509, F-91405 Orsay, France

Clément VIRMOUX, Laboratoire de Géographie Physique, CNRS UMR8591, 1 Place Aristide Briand 92195 Meudon France

Alexander FEDOROV, Permafrost Institute, RAS Siberian branch, Merzlotnaya St., 36, Yakutsk 677010 - Russia

Pavel KONSTANTINOV, Permafrost Institute, RAS Siberian branch, Merzlotnaya St., 36, Yakutsk 677010 - Russia

Maël JAMMET, Université Paris 1 Panthéon-Sorbonne, Laboratoire de Géographie Physique, CNRS UMR8591, 1 Place Aristide Briand 92195 Meudon - France maeljammet@bbox.fr

Daniel BRUNSTEIN- Present address Université de Corse, CNRS, UMR6240 LISA- France

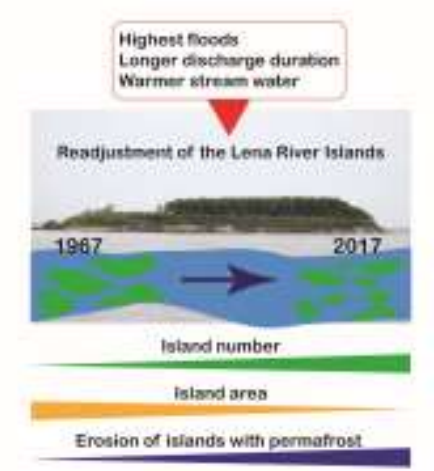

Abstract

The Lena, a large river that drains the northern coldest region of the Northern Hemisphere, is deeply influenced by the continuous permafrost and degradation of the frozen ground has been shown to be the main cause of the marked increase in water discharge. The first objective of this study conducted on the middle Lena was to analyze the island dynamics for the last 50 years (1967 to 2017). Several morphological parameters were surveyed using a GIS on seven series of aerial photographs and satellite images of a $100 \mathrm{~km}$-long reach: island size, eroded and deposited areas, position and morphology of the islands. This approach enabled the identification of evolutionary models. Our second objective was to evaluate the potential impact of ongoing climate change. We analyzed 
morphological parameters with respect to two main factors: efficient discharge (bar-full, bankfull and flood discharges) and water temperature. A potential erosion index (PEI) was calculated by coupling the duration of discharge exceeding the bar-full level and water temperature.

The results identified several morphological changes that occurred at the end of the 20th century: an increase in the number of islands, greater eroded surfaces and accelerated migration of islands. Comparing the dynamics of islands with and without permafrost is a good indicator of their sensitivity to climate change. A major change was observed concerning the erosion and migration of islands with and without permafrost. This evolution seems to be linked both with the duration of the discharge that exceeds the bar-full level and with the number of flood peaks. The water temperature in May and August have a major influence on permafrost islands that become increasingly destabilized. Thus, as large rivers are assumed to slowly react to climate change, the recent changes in the Lena River prove that the global change deeply impacts periglacial rivers.

Keywords: fluvial islands, periglacial river, spatial analysis, anabranching fluvial forms, climate change, Lena River.

\section{Introduction}

Whereas long term fluvial form readjustments to Holocene warming have been widely analyzed water, sediment and vegetation changes causing radical changes in fluvial patterns up to fluvial metamorphosis (Schumm, 1969; Richards, 1982; Starkel et al., 1991; Vandenberghe, 2003; Downs and Piégay, 2019) - little is known about the morphological impacts of the ongoing climate change. As the Arctic is experiencing rapid warming, almost twice as fast as elsewhere (IPCC 2019), many papers have focused on high-latitude rivers and several studies conducted since the beginning of the $21^{\text {st }}$ century on Arctic rivers highlighted important hydrological changes, dominated by a general increase in water flow (Peterson et al., 2002; Serreze et al., 2002). Winter low water discharge has increased significantly, not only in Siberian rivers (Yang et al., 2002; Berezovskaya et al., 2005; Shiklomanov et al., 2007; Gautier et al., 2018; Shpakova et al., 2019), but also in northern Europe (Matti et al., 2016), northern Canada and Alaska (Brabets and Walvoord, 2009; Déry et al., 2009; Bennett et al., 2015; Yang et al., 2015; Rood et al., 2017). Earlier ice-breakups followed by floods are widely reported and an abundant literature is dedicated to fluvial ice thickness and the date of breakup (Pavelsky and Smith, 2004; de Rham et al., 2008; Goulding et al., 2009; Klavins et al., 2009; Prowse et al., 2011; Turcotte and Morse, 2013; Shiklomanov and Lammers, 2014; Park et al., 2016; Morse and Wolfe, 2017). 
Permafrost plays a key role in hydrological behavior and is also widely involved in fluvial dynamics in periglacial regions. In regions with an ice-rich permafrost ("Yedoma", in Siberia and Alaska), the permafrost cover results in low underground water input and specific flooding processes dominated by a very rapid rising limb during breakup (Gautier et al., 2000; Walker and Hudson, 2003; de Rham et al., 2008; Prowse et al., 2011; Costard et al., 2014). Rapid warming, which thaws the permafrost, directly affects the hydrological functioning of rivers (Walvoord and Kurylyk, 2016). The decreasing ratio between maximum and minimum river discharge reflects permafrost degradation which, in turn, enhances low water discharge (Ye et al., 2009; Gautier et al., 2018).

Permafrost must be taken into account in fluvial dynamics, as it modifies the mechanical properties of the frozen banks. The main specificity of periglacial rivers is the combined effect of thermal and mechanical erosion. During the flood season, the stream water causes the thawing line to advance within the frozen banks (Soloviev, 1973; Jahn, 1975; Are, 1983; Gautier and Costard, 2000; Walker and Hudson, 2003; Costard et al., 2014; Kanevskiy et al., 2016; Tananaev, 2016; Chassiot et al., 2020). Thawing of the ice contained in the porous sediment of the riverbank reduces its strength, and produces easily removable uncemented material (Costard et al., 2003). Bank instability can be worsened by bank collapses: thermo-erosional niches are incised into the base of the frozen bank and the remaining upper part then collapses into the river. The temperature of the water stream has been shown to play a predominant role in the thermal erosion of frozen banks (Costard et al., 2003; Dupeyrat et al., 2011). Efficient discharge duration and water stream temperature are thus assumed to jointly destabilize frozen banks.

To precisely evaluate the efficiency of thermal erosion, the studies of rivers generally focus on very precise measurements of bank retreat over short sections of rivers (Walker and Hudson, 2003; Kanevskiy et al., 2016; Tananaev, 2016). The dynamics of and changes in river frozen banks have been studied in detail on few rivers and the studies demonstrate that erosion rates can vary greatly at the same site and between rivers (Are, 1983; Walker and Hudson, 2003; Costard et al., 2007 and 2014; Kanevskyi et al., 2016; Tananaev, 2016; Dupeyrat et al., 2018; Stettner et al., 2018; Payne et a., 2018; Chassiot et al., 2020). In any case, multi-decadal surveys of bank retreat on large rivers in cold environments allowing precise comparison of erosion rates of perennially-frozen (i.e. with permafrost) and seasonally frozen banks are rare (Kanevskyi et al., 2016). Consequently, it is impossible to conclude if the frozen ground accelerates the rate of erosion of the riverbanks, or not. In addition, the evaluation of the impacts of the ongoing hydro-climatic disruption on the periglacial fluvial landforms is an important task.

The Lena River in eastern Siberia drains a deep and continuous permafrost region that is strongly impacted by the current climate change. The middle and low valley presents an anabranching fluvial 
pattern with numerous channels surrounding forested islands. Thus, the Lena River offers the opportunity to investigate the readjustment of an anabranching fluvial system to the ongoing climate change. The fluvial and hydraulic parameters that control the anabranching style have been investigated in numerous studies (Nanson and Knighton, 1996; Huang and Nanson, 2007; Latrubesse, 2008; Kleinhans et al., 2012 and 2013; Carling et al., 2014; Nanson and Huang, 2017, etc.). Descriptions of the island dynamics were relatively rare in the literature as islands were assumed to be stable forms (Ashworth and Lewin, 2012). However, island adjustment capacity to environmental changes at different time scales has been analyzed recently (Hohensinner et al., 2004; Baubiniene et al., 2015; Liu et al., 2016; Hudson et al., 2019; Leli et al., 2020a).

Through a focus on island dynamics from 1967 to 2017 on the Middle Lena River, this paper aims to deal with two main questions. First, assuming that large rivers readjust very slowly to climate change (Schumm, 1977; Vandenberghe, 2003), is it possible to detect morphological changes at a pluridecadal time scale in such large anabranching low-energy rivers? Second, as the Lena is a periglacial river crossing a very cold region with a thick permafrost, what is the impact of the ongoing hydroclimatic change on the fluvial form dynamics, and more specifically, on frozen banks? For that purpose, changes in the fluvial forms over the 50-year period were analyzed on the middle Lena River. We assessed the surface area of the islands by identifying areas of erosion and deposition. The precise analysis of erosion on islands without and with permafrost allows us to compare their dynamics. The diachronic morphological evolution was analyzed with regards to several hydrological parameters: duration, intensity and seasonal distribution of various water discharges. Finally, island evolutionary models were also built to understand their construction.

\section{Study area}

The Lena River is one of the largest Arctic rivers whose course exceeds 4,400 km and flows between the Baikal Range and the Laptev Sea, into which the river pours $525-557 \mathrm{~km}^{3}$ of water, about 20 million tons of suspended sediment and 20-49 million tons of dissolved load every year (Lopatin, 1952; Antonov, 1960; Shiklomanov et al., 2000; Gordeev 2006). 


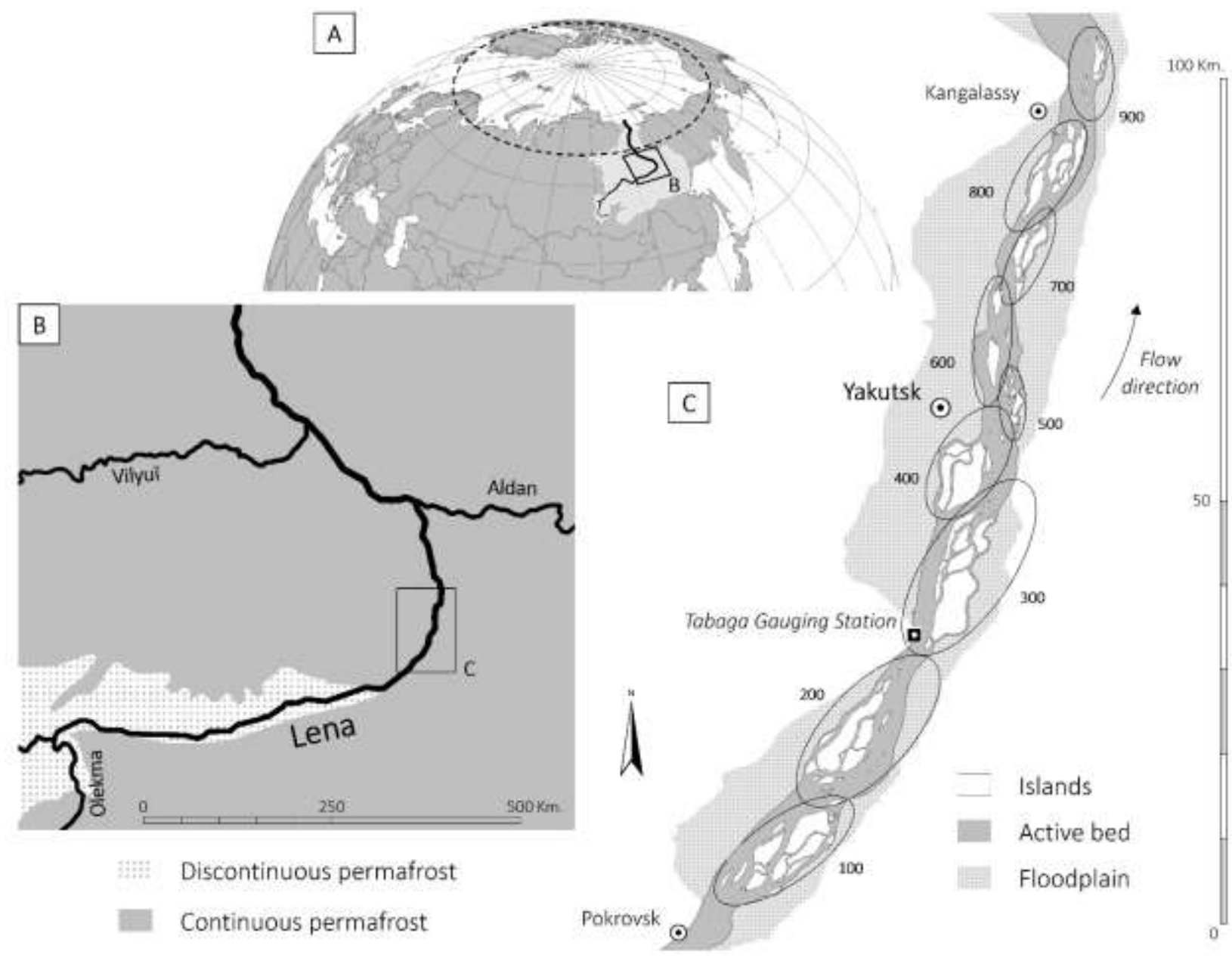

Figure 1. A: Lena River Basin; B: Upper reaches of the Lena River with presence of permafrost according to Brown et al. 1998 (revised Feb. 2001); C: Study area with nine groups of islands.

In the upper valley, the Lena River incises in the Trans-Baikal Highlands and the Archean Aldan Shield, flows through narrow valleys with relatively steep gradients. In the middle and low valley, the river drains the plateaus of the Siberian Platform. Seventy kilometers upstream of Yakutsk, the longitudinal gradient diminishes (0.0001) and the floodplain widens to about $10 \mathrm{~km}$, and farther downstream, to $15 \mathrm{~km}$. The 100-km long study reach covers the section between Pokrovsk, a city located just at the point where the floodplain begins to widen, and Kangalassy (Figure 1).

Eastern Siberia is the coldest region in the Northern Hemisphere, with a deep, ice-rich and continuous permafrost (Antonov, 1960). The mean air temperature at Yakutsk is $-7.8{ }^{\circ} \mathrm{C}$ since the beginning of the $21^{\text {st }}$ century. For the $20^{\text {th }}$ century it ranged between $-10.4{ }^{\circ} \mathrm{C}$ and $-10.8{ }^{\circ} \mathrm{C}$. Precipitation is low, averaging about $230 \mathrm{~mm}$ at Yakutsk, and very irregular. Warming is indeed being accompanied by an increase in summer rainfall and early winter snowfall triggered by abnormal storms in Siberia (Fedorov et al., 2014b; Iijima et al., 2016, 2010; Zhang et al., 2012). 

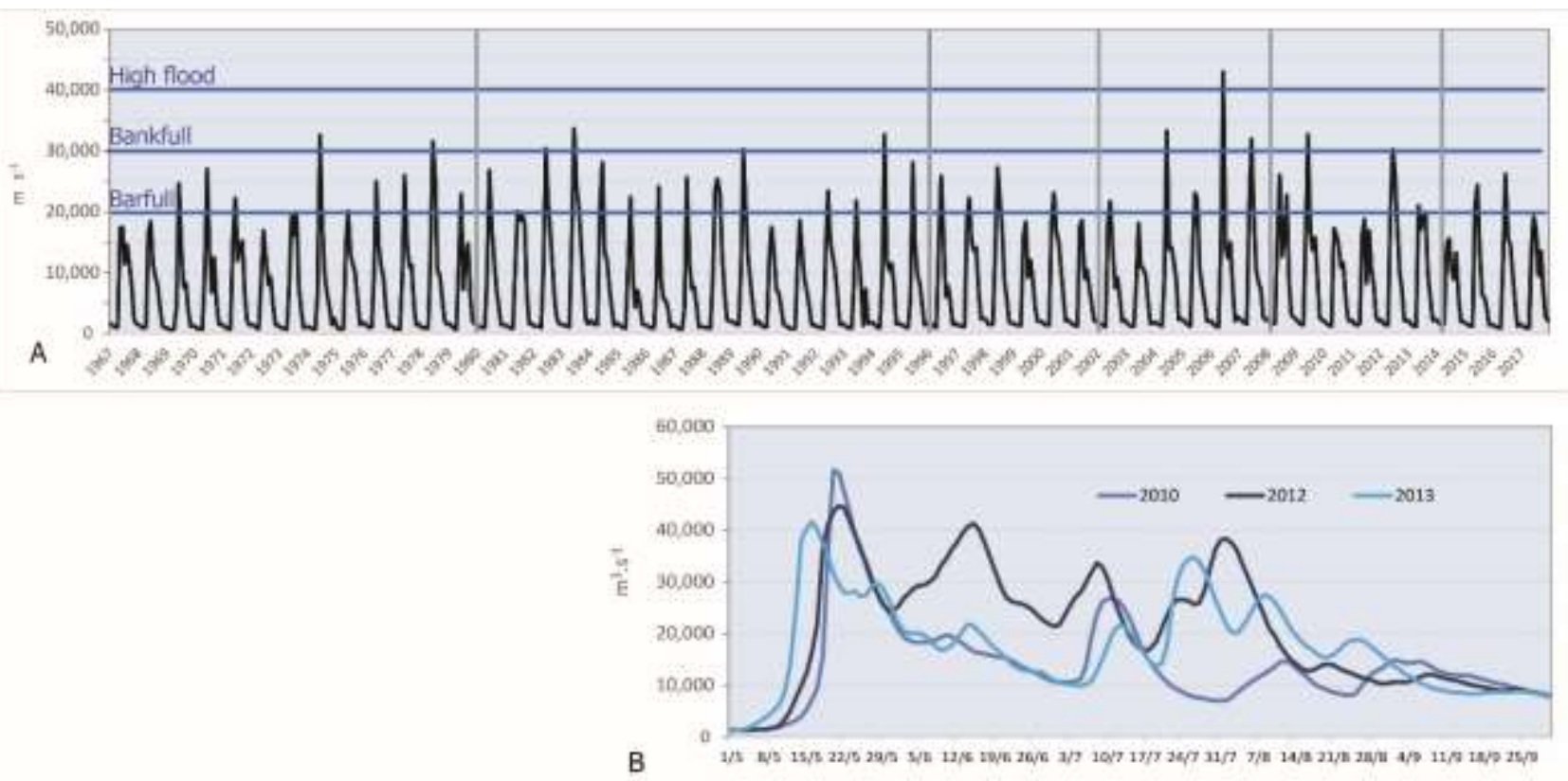

Figure 2. Water discharge of the study period; A: Mean monthly discharge (1967 - 2017); grey vertical lines: study periods; blue lines: water discharge thresholds; B. Examples of recent floods, May-September daily discharge in 2010, 2012 and 2013 (Tabaga station, source: Roshydromet).

The mean annual water discharge recorded at Tabaga gauging station is low and variable; with mean value around $8,300 \mathrm{~m}^{3} \mathrm{~s}^{-1}$ for the last decade (i.e. $8.41 . \mathrm{s}^{-1} \mathrm{~km}^{-2}$, the basin at Tabaga is $987,000 \mathrm{~km}^{2}$; Figure 1; Figure 2A). The river is covered by an ice cap for more than 220 days in winter during the long low water period (Gautier and Costard, 2000; Yang et al., 2002; Costard et al., 2014; Tananaev, 2016). The periglacial fluvial regime of the Lena River is dominated by a flood peak in May or June. A flood wave forms in the upper basin in April with the snow melt. The flood wave propagates downstream in one month and generally reaches the middle valley in the second half of May, when the fluvial bed is still frozen: this triggers the fluvial outburst. The water level increases rapidly and the discharge can be multiplied tenfold or more in just a few days (Figure 2B). Because of the near absence of an underground water supply, the water level drops in summer. However, a secondary flood peak can be caused by summer storms (Figure 2B). Exceptional flood events have been reported recently in Siberia, triggered by more frequent very wet conditions (Shiklomanov and Lammers; 2009; Fedorov et al., 2014b; Iijima et al., 2016; Gautier et al., 2018; Tei et al., 2020).

Two main fluvial patterns are observed in Siberia: meandering fluvial forms in the case of small and medium sized rivers (see for example the Vilyui River in Figure 1), and an anabranching pattern in the case of the Lena River (Gautier and Costard, 2000; Huisink et al., 2002). The Lena is large, in terms of both length and floodplain width. With 16,500 $\mathrm{m}^{3} \mathrm{~s}^{-1}$ at Kyusyur (gauging station located at the entrance of the Lena delta), the river can be defined as a "mega-river" (Latrubesse, 2008). The 
large islands (1 $-5 \mathrm{~km}$ in length) are the predominant feature of the fluvial landscape (Gautier and Costard, 2000). Alluvial vegetation on Lena islands, very homogeneous, is dominated by willows. The islands are 3 to 5 meters above the low water level (Figure A in Supplementary material). As the islands are subject to active mechanical and thermal erosion during floods, their form changes progressively, with a notable retreat of the banks at the island head (and sides) and deposition at the island tail, whereas the channel banks remain relatively stable (Gautier et al., 2008).

\section{Data and Methods}

\subsection{Construction of a GIS on islands}

The study of islands combined different methods and data from different sources. First, the multidecadal changes in islands and in the fluvial bed was surveyed using diachronic analysis. A $100 \mathrm{~km}$ section of river has been studied in different years since 1967 using aerial photographs $(1967,1980)$ and satellite images (1996, 2002, 2008, 2014, 2017), taken during low-water periods (Table 1).

\begin{tabular}{|c|c|c|c|c|c|}
\hline Date & Type & Satellite & Date & $\begin{array}{c}\text { Image } \\
\text { resolution }\end{array}$ & $\begin{array}{c}\text { Number of } \\
\text { islands }\end{array}$ \\
\hline 1967 & Aerial Photographs & Corona KH4A & September 20 & $3 \mathrm{~m}$ & 101 \\
\hline 1980 & Aerial Photographs & Hexagon KH9-16 & September 3 & $7 \mathrm{~m}$ & 108 \\
\hline \multirow{2}{*}{1996} & \multirow{2}{*}{ Satellite images } & \multirow{2}{*}{ Landsat 5} & June 25 & \multirow{2}{*}{$30 \mathrm{~m}$} & 11 \\
\hline & & & September 4 & & 99 \\
\hline 2002 & Satellite images & Landsat 7 & August 12 & $30 \mathrm{~m}$ & 113 \\
\hline \multirow{2}{*}{2008} & \multirow{2}{*}{ Satellite images } & Landsat 5 & June 26 & $30 \mathrm{~m}$ & 11 \\
\hline & & Spot 5 & July 24 & $2.5 \mathrm{~m}$ & 114 \\
\hline \multirow{4}{*}{2014} & \multirow{4}{*}{ Satellite images } & Landsat 8 & July 27 & $30 \mathrm{~m}$ & 2 \\
\hline & & Pleiades & August 26 & $0.5 \mathrm{~m}$ & 96 \\
\hline & & \multirow{2}{*}{ Spot 6} & August 29 & \multirow{2}{*}{$1.5 \mathrm{~m}$} & 10 \\
\hline & & & September 11 & & 33 \\
\hline \multirow{2}{*}{2017} & \multirow{2}{*}{ Satellite images } & \multirow{2}{*}{ Pleiades } & July 29 & \multirow{2}{*}{$0.5 \mathrm{~m}$} & 100 \\
\hline & & & August $2,8,14$ & & 54 \\
\hline
\end{tabular}

Table 1. Aerial photographs and satellite images used. 
After georeferencing, fluvial forms were digitized from each image in a GIS based on the limit between perennial vegetation and areas without vegetation (active channels and bars, Figure $\mathrm{A}$ in Supplementary material). In fluvial geomorphology, perennial vegetation is a common indicator used to distinguish very mobile forms with no perennial vegetation or "stabilized" forms. Stabilization takes place via the progression of the pioneer sequences down the island. Willow growth is clearly visible in remote sensing images, so the progression of the alluvial vegetation reflects stabilization of the form. Identification is easy from imagery, especially in the case of large rivers, and allows islands to be isolated from the active bed (Hudson et al., 2019; Marchetti; 2013). Three main fluvial forms were identified and digitized: (i) the fluvial bed; (ii) island banks and (iii) the active bed. The fluvial bed was defined by the limit of perennial vegetation on its right and left banks, it includes the active river bed and the islands. Islands are defined as deposition forms surrounded by two active channels and colonized by perennial vegetation. The active bed is composed of all channels that are connected with the main channel upstream and downstream and that are submerged and/or occupied by sand bars, depending on the water level. It is obtained by subtracting the shapes of the islands from the fluvial bed.

Image resolution is not uniform over the 50-year period considered, varying from a few metres or less to 30 metres: high resolution is available for the 1967 and 1980 photographs and a very high resolution for the recent images (2014 and 2017), while the sources available for 1996 and 2002 are of lower resolution (Table 1). However, the pluri-annual time span between two images allows us to limit the bias ( 6 years and more) and this disparity has been taken into account during the vectorisation which was carried out at a similar scale whatever the resolution of the source image (approximately $1 / 10,000 \mathrm{e})$. In addition, if the changes measured over a time interval are less than the resolution of the images used, then the shapes are considered stable.

\subsection{Analytical parameters}

\subsubsection{Changes in island form}

To track and compare islands over time, each island has a unique identifier based on their belonging to one of nine groups of islands identified from upstream to downstream (Figure 1C). Several parameters are recorded each year: the banks limiting the fluvial bed and the floodplain, the number of islands, surface area, width and length (based on a minimum bounding geometry), position of the head (upstream limit), which is manually digitalized and of the centroid, which is generated (Figure 3A; Figure A in Supplementary material). 
For each period between two consecutive dates, the mobility of the islands was investigated by focusing on island migration, and on changes in the sites of erosion and deposition. Changes at the head of the island give the impression of migration: downstream in the case of erosion, upstream in the case of sedimentation. The distance measured between the position of the head in year YYY1 and in year YYY2 was used to calculate the average rate of erosion or sedimentation. Comparison of the orientation of the line formed by the two heads of an island in years YYY1 and YYY2 with that of the line formed by the head of an island and its centroid in year YYY1 shows the direction of migration and consequently the major sedimentary process for the period (Figure 3A). For a better understanding of the evolution process, we distinguish between three types of islands: (i) islands located in the central part of an active channel without bar or island located just upstream that could have inhibited its erosion; (ii) lateral islands without bar or island located upstream and (iii) islands with a bar or island located just upstream (Costard et al., 2007).
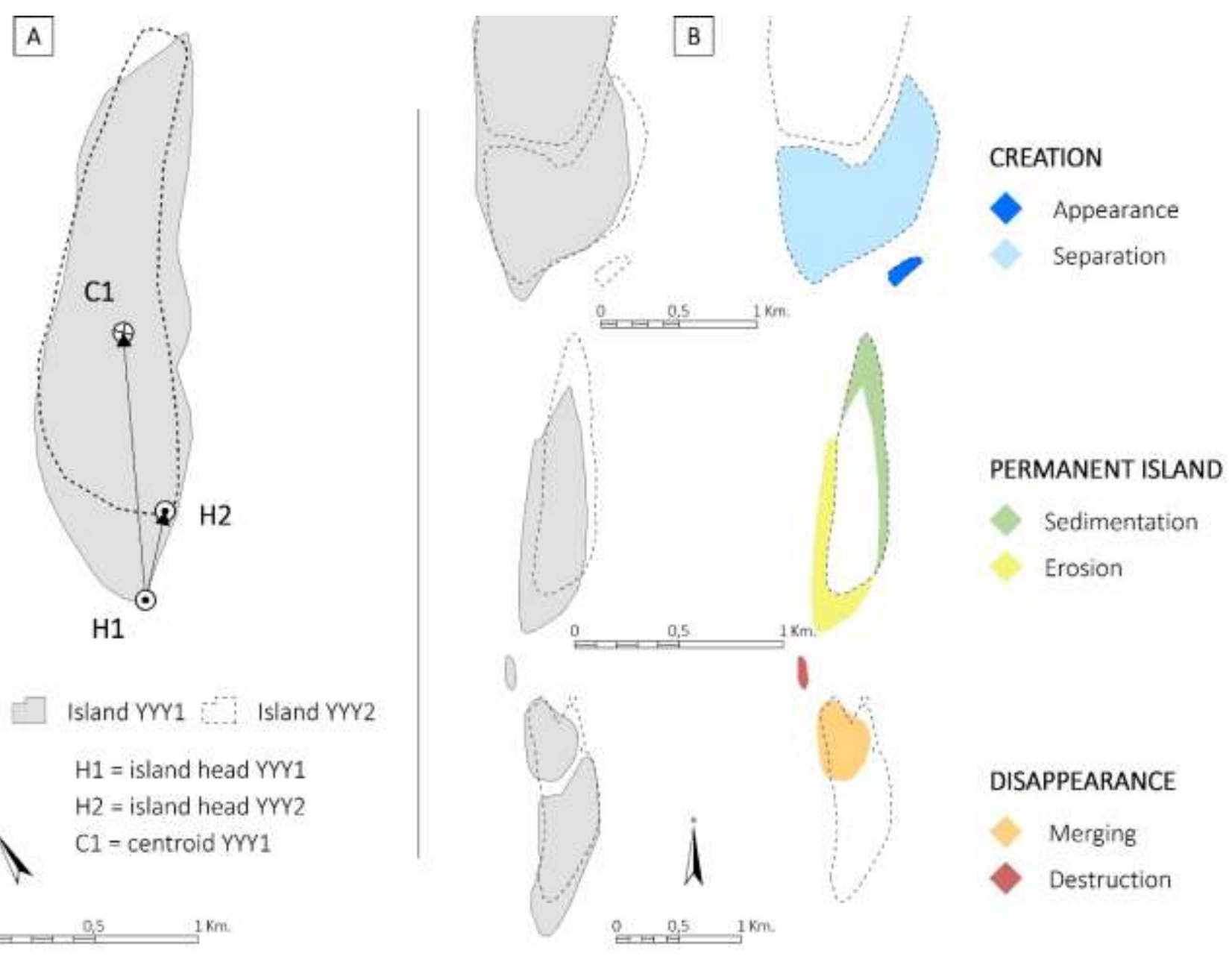

Figure 3. A: The analytical parameters of the islands $(\mathrm{H} 1 / \mathrm{C} 1=$ island $\mathrm{YYY} 1$ orientation, $\mathrm{H} 1 / \mathrm{H} 2=$ island head migration); B: Changes in surface area and island trajectories of change. 
Concerning the changes in the surface area of the islands, we computed erosion and deposition areas, the majority of islands being subjected to both processes simultaneously at each time interval (Figure 3B). Erasing the shape of year YYY1 with that of year YYY2 reveals the eroded areas, the shape of year YYY2 with that of year YYY1 reveals the areas with deposits. Erosion and deposition lead to three possible main types of change (Figure $3 B$ ):

i) The "creation" of an island can be the result of two different processes: colonization of a bar by the alluvial vegetation or opening of a new channel separating an existing island into two parts,

ii) maintenance of a "permanent" island (i.e. an island present from one date to another), on which erosion and sedimentation occur simultaneously,

iii) The "disappearance" of an island can be the result of a total erosion of a form or by the merging of one island into another one (or into the bank).

Together, these results in six possible trajectories of change defined by logical spatial relationships (Figure $3 \mathrm{~B}$ ) that make it possible to give a systematic account of the history of the islands.

\subsubsection{Islands with and without permafrost}

Finally, we calculated the age of the islands based on the year of their appearance. Our objective was to identify a possible difference in erosion rates between perennially-frozen islands and islands without permafrost (only frozen in the winter). To check for the presence of permafrost, many islands were investigated in four successive summers: first, the banks were described and soil temperature inside the banks was measured. Second, by drilling different parts of the islands, we determined the thickness of the active layer and located the top of the permafrost. Two islands were also equipped with temperature sensors installed in different parts of the permafrost, in the active layer, in the water, and in the air (see Costard et al., 2014, for methodological details). The age of the islands present in the first data source (Corona photographs taken in 1967) was set at 1 by convention. The real age of these islands is unknown, the age attributed is therefore their minimum age because we do not know how long they existed prior to 1967. The oldest islands that are visible are thus at least 50 years old (66 islands between 1967 and 2017).

\subsection{Control factors}

\subsubsection{Hydrology parameters}


A long time series of water discharge has been available at Tabaga gauging station on the Middle Lena River (Figure 1) since 1936. Three discharge classes were identified based on their morphological effects (Figure 2A). The thresholds have been determined during field observations and according to the Navigation Survey.

i) Bar-full discharge to bankfull discharge (ranging from 20,000 to 30,000 $\mathrm{m}^{3} \mathrm{~s}^{-1}$ ) ranges from the level that submerges barren bars and the top of the water level before overbank submersion (Costard et al., 2014; Tananaev, 2016; Gautier et al., 2018). It lasts about 30 days a year. When this water level reaches the base of the bank, thermal and fluvial erosion begins.

ii) Frequent flood $\left(30,000\right.$ to $\left.40,000 \mathrm{~m}^{3} \mathrm{~s}^{-1}\right)$ lasts about 8 days a year,

iii) High flood discharge $\left(>40,000 \mathrm{~m}^{3} \mathrm{~s}^{-1}\right)$ had a mean annual duration lower than one day a year at the beginning of the study period; nowadays it can last $2-5$ days.

The duration of the three discharge classes was calculated for each year since 1967 using the peakover-threshold method (Lang et al., 1999). We also calculated the number of flood peaks per year using Lang's method, distinguishing spring flood peaks (May and June) and summer flood peaks (July, August and September), since the water stream temperature is warmer in summer, thus accelerating the thermal erosion of the frozen banks.

\subsubsection{Air and water temperature}

Daily air temperature at Yakutsk has been recorded since July 1888. We recorded soil temperature (in both seasonally and perennially frozen islands) and water stream temperatures at four hourly intervals in six years (2008-2013) in the Lena River with hobo and thermo-buttons installed on two islands in the vicinity of Tabaga station (Konstantinov et al., 2011). We also used the daily water stream temperatures provided by the Navigation Service at 10 day intervals between 2008 and 2011. To extrapolate the water temperature to the whole study period, we calculated the relation between air and water temperature. Because of water temperature inertia, two equations were calculated with a good relation (for May and June $\mathrm{R}^{2}=0.8814$ and for July to September $\mathrm{R}^{2}=0.9496$ ).

The first equation for May and June is:

$$
\mathrm{T}^{\circ} \text { Water }=1.0887 \mathrm{~T}^{\circ} \text { Air }-5.9744
$$

The second equation for July to September is:

$$
T^{\circ} \text { Water }=0.7542 T^{\circ} \text { Air }+4.8423
$$


As water temperature and water discharge are jointly responsible for erosion of frozen banks, we calculated a "potential erosion index", PEI) as follows for the present study:

$$
P E I=T^{\circ} \text { Water } * N D 20
$$

where ND20 is the number of days on which discharge exceeded $20,000 \mathrm{~m}^{3} \mathrm{~s}^{-1}$.

Finally, we examined Spearman's nonparametric correlations between the mean annual value of these controlling factors and the mean annual values of the parameters describing the morphological changes.

\section{Results}

4.1. General trends during the 50-year study

A slight increase in the fluvial bed area (including active channels and islands) was observed (+25 $\mathrm{km}^{2}$, i.e. $\left.+4.1 \%\right)$ over the study period (1967-2017). The increase is the results of a low erosion of the fluvial bed banks, with an average about 3-4 m per year. The bank erosion represents only $0.05-0.1 \%$ of the river width and it is mainly due to local retreats. No avulsion was observed. The fluvial bed banks can be considered as stable at this temporal scale, it is the islands that are in fact responsible for the change. Vegetated islands account for a mean value of one third of the area of the fluvial bed (Figure 4). In 1967, 101 islands were identified, and 154 islands in 2017 (i.e. $+52 \%$ since 1967). Their proportion of the fluvial bed clearly increased between 1967 and 2008: $188 \mathrm{~km}^{2}$ in 1967, versus 220 $\mathrm{km}^{2}$ in 2008. A slight decrease in the part occupied by the islands was detected after 2008. 

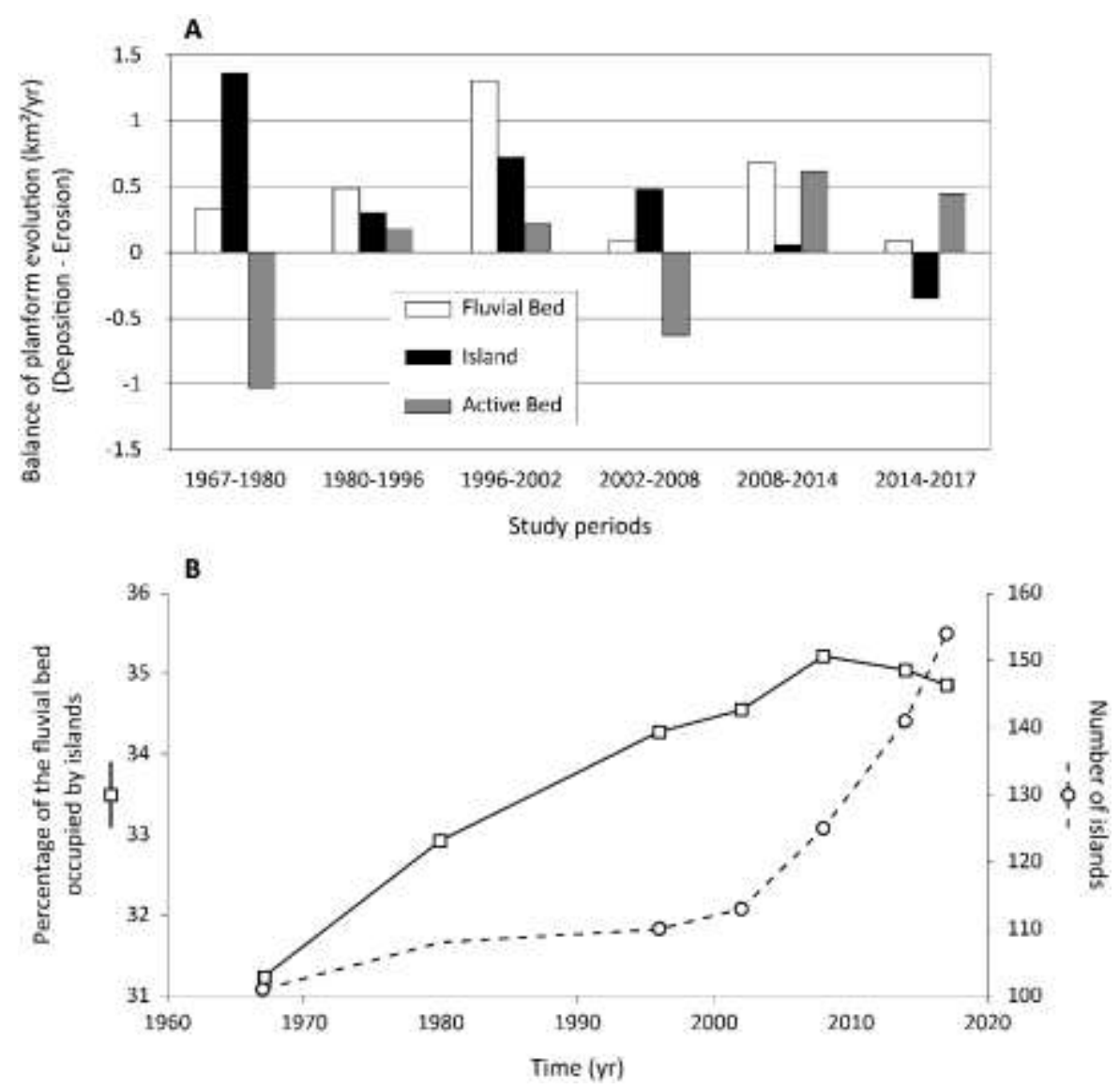

Figure 4. A: Mean annual evolution of fluvial bed area, island area and active bed area between 1967 and 2017 (Fluvial bed area includes active bed and island areas). B: percentage of the fluvial bed occupied by islands and number of islands for each study date.

\subsection{Detailed changes to the islands}

A general decreasing trend is detected in the deposition areas, which ranged between 1.2 and $2.5 \mathrm{~km}^{2}$ annually in the whole study zone. The highest deposition rates were recorded in the first period (19671980, Table 2), and in the third period (1996 - 2002). The deposited area per island declined by $45-$ 47\% after 2002 (Figure B in Supplementary material). 
1 Table 2. Morphological parameters $1967-2017$.

\begin{tabular}{|c|c|c|c|c|c|c|c|}
\hline & & $1967-1980$ & $1980-1996$ & $1996-2002$ & $2002-2008$ & $2008-2014$ & $2014-2017$ \\
\hline \multirow{6}{*}{ Mean evolution } & Active bed area $\mathrm{km}^{2} \cdot \mathrm{yr}^{-1}$ & -1.03 & 0.18 & 0.21 & -0.63 & 0.62 & 0.44 \\
\hline & Island area $\mathrm{km}^{2} . \mathrm{yr}^{-1}$ & 1.36 & 0.3 & 0.73 & 0.48 & 0.06 & -0.35 \\
\hline & $\begin{array}{l}\text { Mean total deposition } \\
\text { areas } \mathrm{km}^{2} \cdot \mathrm{yr}^{-1}\end{array}$ & 2.45 & 1.38 & 2.53 & 2.19 & 1.69 & 1.19 \\
\hline & $\begin{array}{l}\text { Mean deposition area per } \\
\text { island } \mathrm{km}^{2} \cdot \mathrm{yr}^{-1}\end{array}$ & 0.0227 & 0.0126 & 0.0226 & 0.0177 & 0.0122 & 0.0079 \\
\hline & $\begin{array}{l}\text { Mean total erosion area } \\
\mathrm{km}^{2} . \mathrm{yr}^{-1}\end{array}$ & 1.09 & 1.07 & 1.8 & 1.47 & 1.63 & 1.54 \\
\hline & $\begin{array}{l}\text { Mean eroded area per } \\
\text { island } \mathrm{km}^{2} \cdot \mathrm{yr}^{-1}\end{array}$ & 0.0109 & 0.0101 & 0.0167 & 0.0130 & 0.0133 & 0.0112 \\
\hline \multirow{2}{*}{$\begin{array}{l}\text { "Appearance" } \\
\text { Creation of new } \\
\text { islands }\end{array}$} & Number / n.yr ${ }^{-1}$ & $21 / 1.6$ & $18 / 1.12$ & $9 / 1.5$ & $18 / 3$ & $22 / 3.7$ & $6 / 2$ \\
\hline & $\begin{array}{l}\text { Mean area evolution } \\
\mathrm{km}^{2} \cdot \mathrm{yr}^{-1}\end{array}$ & 0.541 & 0.142 & 0.148 & 0.113 & 0.230 & 0.031 \\
\hline \multirow{2}{*}{$\begin{array}{l}\text { "Disappearance" } \\
\text { Totally eroded islands }\end{array}$} & Number / n.yr ${ }^{-1}$ & $11 / 0.85$ & $7 / 0.43$ & $2 / 0.33$ & $3 / 0.5$ & $2 / 0.33$ & 0 \\
\hline & $\begin{array}{l}\text { Mean area evolution } \\
\mathrm{km}^{2} \cdot \mathrm{yr}^{-1}\end{array}$ & -0.0041 & -0.045 & -0.029 & -0.0013 & -0.016 & \\
\hline
\end{tabular}




\begin{tabular}{|c|c|c|c|c|c|c|c|}
\hline "Growing islands" & Number & 51 & 42 & 48 & 65 & 42 & 56 \\
\hline $\begin{array}{l}\text { Islands gaining } \\
\text { surface }\end{array}$ & $\begin{array}{l}\text { Mean area evolution } \\
\mathrm{km}^{2} \cdot \mathrm{yr}^{-1}\end{array}$ & 1.176 & 0.956 & 1.676 & 1.716 & 0.734 & 0.417 \\
\hline "Eroding islands" & Number & 34 & 50 & 53 & 37 & 74 & 84 \\
\hline $\begin{array}{l}\text { Islands loosing } \\
\text { surface }\end{array}$ & $\begin{array}{l}\text { Mean area evolution } \\
\mathrm{km}^{2} \cdot \mathrm{yr}^{-1}\end{array}$ & -0.276 & -0.409 & -0.933 & -0.699 & -0.848 & -0.809 \\
\hline \multirow{2}{*}{ Migration } & Head retreat $\mathrm{m} . \mathrm{yr}^{-1}$ & 14.6 & 13.4 & 20.5 & 16 & 17.5 & 14.3 \\
\hline & Lateral retreat $\mathrm{m} . \mathrm{yr}^{-1}$ & 8.8 & 6.9 & 10.3 & 9.4 & 9.2 & 8 \\
\hline
\end{tabular}

2 
4 The variations in deposition and erosion area of the islands have not been exactly synchronous. The 5 eroded surface area was $1.07-1.09 \mathrm{~km}^{2}$ per year from 1967 to 1996 . The mean annual eroded surface

6 reached $1.8 \mathrm{~km}^{2}$ between 1996 and 2002. Eroded area slightly declined after 2002 (Figure B in

7 Supplementary material).

8 Due to the variability of deposition and erosion, the mean area of the islands varied greatly over the

9 course of the 50-year period. The first period of rapid island accretion (1967-1980) was accompanied 10 by a net increase in both the median value $(+37 \%)$ and minimum surface area $(+25 \%)$ of the islands. 11 Since 2008, all parameters have decreased considerably with $0.19 \mathrm{~km}^{2}, 1.42 \mathrm{~km}^{2}$ and $0.04 \mathrm{~km}^{2}$, for 12 the median, mean and first quartile, respectively, in 2017 (Figure B in Supplementary Material). The 13 marked reduction in the median value and in the minimum value are evidence for the recent creation 14 of numerous islets.

\subsection{Island trajectory}

17 It was possible to monitor more than $50 \%$ of islands for a period of 50 years. The second half was 18 surveyed for a shorter time step: some islands disappeared due to erosion and still other islands have been created (Table 2; Figure 5). 


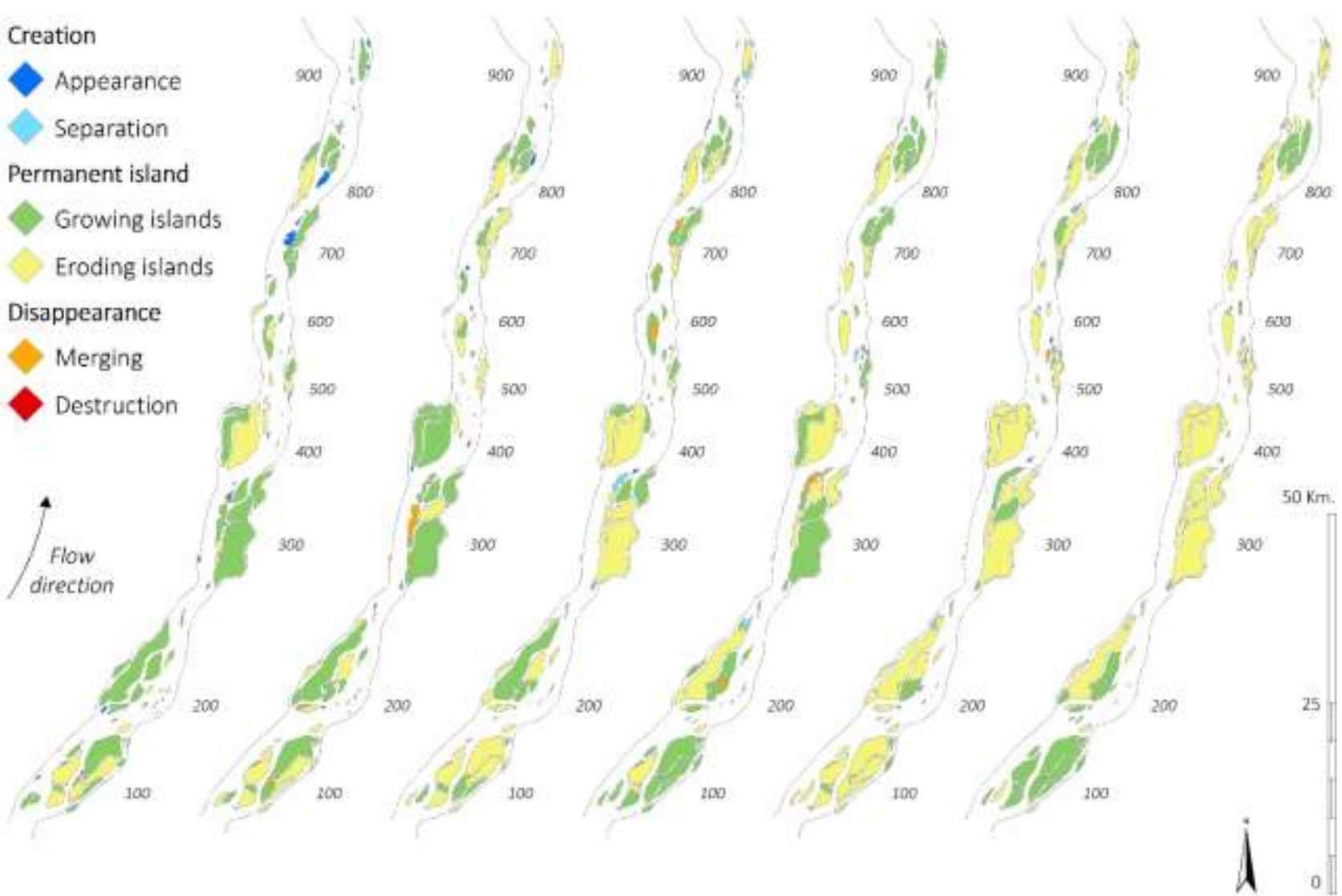

Figure 5. Main trajectories of islands (1967-2017).

\subsubsection{Appearance and evolution of islands}

The creation of new islands ("Appearance" in Figure 5) and their growth rate varied considerably. From 1967 to 1980, an average of 1.6 new islands were created each year, making it an important process in terms of surface area $\left(+0.5 \mathrm{~km}^{2}\right.$ per year). Each new island grew rapidly. Since 2002 , more than three islands have been created every year, but the growth rate of these young islands is much slower (Table 2). This confirms our first observation concerning the recent multiplication of small islands.

Three main geomorphologic configurations can be observed for island creation. i) A mid-channel bar develops and its central part is colonized by pioneer sequences. ii) The stabilization of a bar can also occur upstream of an existing island, as deposition is controlled by diversion of the flow caused by the existing island (section 800, 1967-1980 in Figure 5). An upstream bar then forms in this low velocity zone which subsequently progrades downstream, it is progressively colonized by the pioneer vegetation. iii) New islands form downstream of an existing island. This "in the lee" location causes 
successive islets to form (section 300, 1996 - 2002 in Figure 5). Finally, the creation of a new island by an avulsion (see "Separation" in Figure 5), with a new channel crossing an island, occurs rarely on the middle Lena River (only 18 in 50 years). No avulsion through the floodplain has been observed since 1967.

The term "Permanent islands" refers to islands we were able to analyze precisely over several decades (Figure 5). Two main forms of permanent islands, which do not develop in the same way, coexist in the Lena River. The first type is that of isolated islands, located in the center of a wide active channel. These islands are elongated (the length:width ratio ranges from 3 to 6 with a mean area ranging between 1 and $5 \mathrm{~km}^{2}$ ), they undergo major morphological changes as the result of intense erosion of their head and/or their flanks and deposition on their tail (see section 100 and section 200 in Figure 5). They may increase in size by annexing a bar or another island formed downstream.

The second type is the composite islands that have generally been formed by accretion on the tail and merging of different islands. They are bigger than the elongated forms, their surface area ranges between 6 and $25 \mathrm{~km}^{2}$ and they may occupy half or more of the width of the fluvial bed. They develop thanks to the downstream and lateral accretion of the island. Islands can also be merged together (Figure 5 "merging"): the process is not common, since in total only 37 islands have merged with another. The presence of lakes, troughs, or small ponds reveals the location of the former inter-islands channels.

\subsection{2. "Growing" and "eroding" islands}

Some islands grew ("growing islands") and some shrank ("eroding islands"; Table 2). Figure 5 highlights the abrupt recent change. At the beginning of the study period, the growing group (in green in Figure 5) represented approximately half the total number of islands. The accretion rate decreased abruptly after 2008 whereas "Eroding islands" (in yellow in Figure 5) suddenly jumped: they represented between one third and half the islands in 2008, and more than two thirds since then. Both their length and width have abruptly declined after 2008 .

The erosion mainly concerns island head (for $80-85 \%$ of the islands) and to a lesser extent, island side. This process gives the impression the island is migrating downstream. The island head erosion is always more accentuated (1.5 - 2 times) than the lateral bank retreat (Table 2). The average erosion rate of the island heads ranged from $14 \mathrm{~m}$ to $20 \mathrm{~m}$ per year and the highest rates were recorded during the period 1996-2002 (20.5 m per year) and the period 2008-2014 (17.5 m per year).

The head retreat depends on the position of the island and on the presence (or not) of another island formed immediately upstream (or a sand bar). The islands located in the center of the channel without 
another island or bar just upstream (Type 1), erode rapidly and some reached a maximum retreat of between 40 and $50 \mathrm{~m}$ per year (and even more). Lateral erosion particularly affected islands located near the channel bank or in a curve (Type 2). Island with an upstream bar or island (Type 3) erode slowly (Figure D in Supplementary material).

Twenty-five islands disappeared completely over the course of the 50-year study period, they were completely eroded ("Destruction" in Figure 5). The majority of these islands were eroded before 2008. All but one of these islands were located in the central part of the main channel and were often isolated. The eroded islands were small $\left(<110,000 \mathrm{~m}^{2}\right)$.

\subsection{Relations between island dynamics and hydrological functioning}

4.4.1. Hydrological change and fluvial form adjustment

Our overall goal is to better understand to what extent the change in the behavior of islands is determined by climate change and its hydrological consequences. Thus, we have explored the links between the morphometric changes and hydrological parameters focusing on the high water period (May to September).

The mean annual discharge recorded at Tabaga gauging station has increased strongly since 1967 (Table 3; Figure 2). The duration of the water levels is therefore changing. However, the three classes of discharge (bar-full, bank-full and large flood) did not vary exactly synchronously. The longest durations were recorded between 2002 and 2008, except for the first discharge class for which the maximum duration was recorded in the last period.

Table 3. Main hydrological features in the study periods (in bold: maximal values)

\begin{tabular}{|l|l|l|l|l|l|l|}
\hline & $1967-1980$ & $1980-1996$ & $1996-2002$ & $2002-2008$ & $2008-2014$ & $2014-2017$ \\
\hline $\begin{array}{l}\text { Mean annual discharge } \\
\mathrm{m}^{3} \cdot \mathrm{s}^{-1} \text { (Tabaga) }\end{array}$ & 6882 & 7170 & 7620 & $\mathbf{8 4 7 3}$ & 8315 & 7342 \\
\hline $\begin{array}{l}\text { Mean annual duration } \\
\text { (days) of bar-full to bank- } \\
\text { full level } \\
20000<\mathrm{Qw}<30000 \mathrm{~m}^{3} \cdot \mathrm{s}^{-1}\end{array}$ & 30.8 & 31.8 & 26.7 & $\mathbf{2 9 . 7}$ & 25 & $\mathbf{3 5}$ \\
\hline $\begin{array}{l}\text { Mean annual duration } \\
\text { (days of overbank } \\
\text { frequent floods } \\
30000<\mathrm{Qw}<40000 \mathrm{~m}^{3} \cdot \mathrm{s}^{-1}\end{array}$ & & 11.1 & 11.5 & $\mathbf{1 3 . 5}$ & 11.8 & 6.3 \\
\hline
\end{tabular}




\begin{tabular}{|l|l|l|l|l|l|l|}
\hline $\begin{array}{l}\text { Mean annual duration } \\
\text { (days) of large floods } \\
\mathrm{Qw}>40000 \mathrm{~m}^{3} \cdot \mathrm{s}^{-1}\end{array}$ & 0 & 0.9 & 1.3 & $\mathbf{5 . 2}$ & 3 & 1 \\
\hline $\begin{array}{l}\text { Mean annual duration } \\
\text { (days) } \mathrm{Qw}>20000 \mathrm{~m}^{3} \cdot \mathrm{s}^{-1}\end{array}$ & 37.1 & 43.8 & 39.5 & $\mathbf{4 8 . 3 3}$ & 39.8 & 42.3 \\
\hline $\begin{array}{l}\text { Mean Spring duration } \\
\text { (days) } \mathrm{Qw}>20000 \mathrm{~m}^{3} \cdot \mathrm{s}^{-1}\end{array}$ & 30.1 & 28.4 & 33.3 & $\mathbf{3 5 . 8}$ & 25.7 & 34 \\
\hline $\begin{array}{l}\text { Mean Summer duration } \\
\text { (days) Qw }>20000 \mathrm{~m}^{3} \cdot \mathrm{s}^{-1}\end{array}$ & 7 & 11.9 & 6.2 & 12.5 & $\mathbf{1 3 . 7}$ & 8.3 \\
\hline $\begin{array}{l}\text { Mean annual number of } \\
\text { flood peaks }\end{array}$ & 1.62 & 1.38 & 1.5 & 1.67 & 2.67 & $\mathbf{3 . 3 3}$ \\
\hline
\end{tabular}

92

93

Flood durations (discharges $>30,000 \mathrm{~m}^{3} . \mathrm{s}^{-1}$ ) were also longer and exceptional durations (i.e. more than 50 days a year) were recorded from 2002 to 2014, 79 days of flooding in 2012 (mean annual discharge of 10,205 $\mathrm{m}^{3} \mathrm{~s}^{-1}$ ) and 55 days in 2013 (Figure 2B). In these years, precipitation largely exceeded the mean annual value. Spring floods generally occur during the second half of May or early June and they are much longer than summer high water levels (from July to September; Figure 2B). The flood peaks determined using the POT method (Lang et al., 1999) also revealed a net increase since the beginning of the $21^{\text {st }}$ century: up to four flood peaks were recorded at Tabaga in 2012, 2013, 2016 and 2017 (Table 3; Figure 2B). The second highest flood recorded since 1936 occurred in May $2010\left(51,600 \mathrm{~m}^{3} \cdot \mathrm{s}^{-1}\right.$ at Tabaga, Figure 2B).

We investigated possible links between the different morphological parameters (surface area, accretion and erosion area and migration rate) with the three discharge classes and with flood peak frequency. The first discharge class (from the bar-full to the bank-full stage) seems to at least partially control changes to the islands. More specifically, deposition is linked to the duration of the first and second class of discharge occurring in spring (Spearman coefficient of 0.509 for the first discharge class and 0.491 for the second class, $\mathrm{p}<0.0001$ ). Concerning eroded areas, robust correlations are found with several hydrologic parameters (duration $>20,000 \mathrm{~m}^{3} \mathrm{~s}^{-1}$ in May; number of flood peak in August; number of peaks $>30,000 \mathrm{~m}^{3} \mathrm{~s}^{-1}$ in May; number total of peaks $>30,000 \mathrm{~m}^{3} \mathrm{~s}^{-1}$; Table 4).

The erosion of the island banks (head and sides) varied greatly depending on the location of the island in the channel, as discussed above. However, when we analyzed each type of island separately relative to the three discharge classes, the erosion of Type 1 (island located in the center of the channel) depends on the duration of discharge exceeding the bank-full level, and on the number of floods peaks. Type 2 (lateral island) and Type 3 (located downstream a bar/island) depended partially on the duration of the bar-full to bank-full stage. 


\begin{tabular}{|c|c|c|c|}
\hline $\begin{array}{l}\text { Morphological } \\
\text { parameter }\end{array}$ & Control variable & Spearman $\mathrm{r}^{2}$ & p-value \\
\hline \multirow[t]{2}{*}{ Deposition area } & $\begin{array}{l}\text { Duration of discharge } 20,000- \\
30,000 \mathrm{~m}^{3} \cdot \mathrm{s}^{-1}\end{array}$ & 0.509 & $<0.0001$ \\
\hline & $\begin{array}{l}\text { Duration of discharge } 30,000- \\
40,000 \mathrm{~m}^{3} \cdot \mathrm{s}^{-1}\end{array}$ & 0.491 & $<0.0001$ \\
\hline \multirow[t]{5}{*}{ Erosion area } & $\begin{array}{l}\text { Duration of discharge }>20,000 \\
\mathrm{~m}^{3} . \mathrm{s}^{-1} \text { in May }\end{array}$ & 0.6 & 0.0724 \\
\hline & Number of flood peaks in May & 0.89 & 0.0048 \\
\hline & Number of flood peak in August & 0.67 & 0.0458 \\
\hline & $\begin{array}{l}\text { Total number of flood peak > } \\
30,000 \mathrm{~m}^{3} \cdot \mathrm{s}^{-1}\end{array}$ & 0.57 & 0.0835 \\
\hline & PEI in May & 0.784 & 0.033 \\
\hline \multirow[t]{3}{*}{$\begin{array}{c}\text { Island bank erosion } \\
\text { (Type 1) }\end{array}$} & $\begin{array}{l}\text { Duration of discharge }>20,000 \\
\mathrm{~m}^{3} \cdot \mathrm{s}^{-1}\end{array}$ & 0.687 & 0.058 \\
\hline & $\begin{array}{l}\text { Duration of discharge } 30,000- \\
40,000 \mathrm{~m}^{3} \cdot \mathrm{s}^{-1}\end{array}$ & 0.640 & 0.083 \\
\hline & PEI in May & 0.889 & $<0.0001$ \\
\hline $\begin{array}{c}\text { Island bank erosion } \\
\text { (Type 2) }\end{array}$ & $\begin{array}{l}\text { Duration of discharge } 20,000- \\
30,000 \mathrm{~m}^{3} \cdot \mathrm{s}^{-1}\end{array}$ & 0.351 & $<0.0001$ \\
\hline $\begin{array}{c}\text { Island bank erosion } \\
\text { (Type 3) }\end{array}$ & $\begin{array}{l}\text { Duration of discharge } 20,000- \\
30,000 \mathrm{~m}^{3} \cdot \mathrm{s}^{-1}\end{array}$ & 0.298 & $<0.0001$ \\
\hline \multirow{2}{*}{$\begin{array}{c}\text { Islands with } \\
\text { permafrost (Type 1 P) }\end{array}$} & PEI in May & 0.640 & 0.083 \\
\hline & PEI in August & 0.640 & 0.083 \\
\hline
\end{tabular}

\subsubsection{Combined effect of discharge duration and water temperature}

As a consequence of the warming, the water temperature is rising: $+1.33{ }^{\circ} \mathrm{C}$ between May and 121 September, the two main flooding months show the highest value $+1.82{ }^{\circ} \mathrm{C}$ in May and $+2.22{ }^{\circ} \mathrm{C}$ in 122 June. The highest temperatures were recorded between 2008 and 2014.

123 The potential erosion index (PEI), which combines duration and water temperature, revealed a net change between the beginning of the study period (PEI=366 in 1967) and the beginning of the $21^{\text {st }}$ 
century $(\mathrm{PEI}>500)$. Although the rise concerned every month, two months in particular, May and August are impacted (Figure 6). The PEI in May was characterized by two rising phases. The first rise occurred in 1996-2002, when the PEI doubled (38.6 versus 18.5 before), which probably explains the reinforced mobility of the fluvial forms observed for this timespan. Second, between 2008 and 2014, the PEI "jumped" to 50.14 in May. August showed the same trend. This change can be explained by the increasing water temperature, and also by the recent multiplication of secondary flood peaks in summer. Both eroded surfaces and island head retreat (Type 1; Table 4) were closely correlated with the PEI in May. Even if no strong statistical correlation was found, we can assume that the highest head retreats measured between 2008 and 2014, were also determined by the maximum PEI values in July and August.
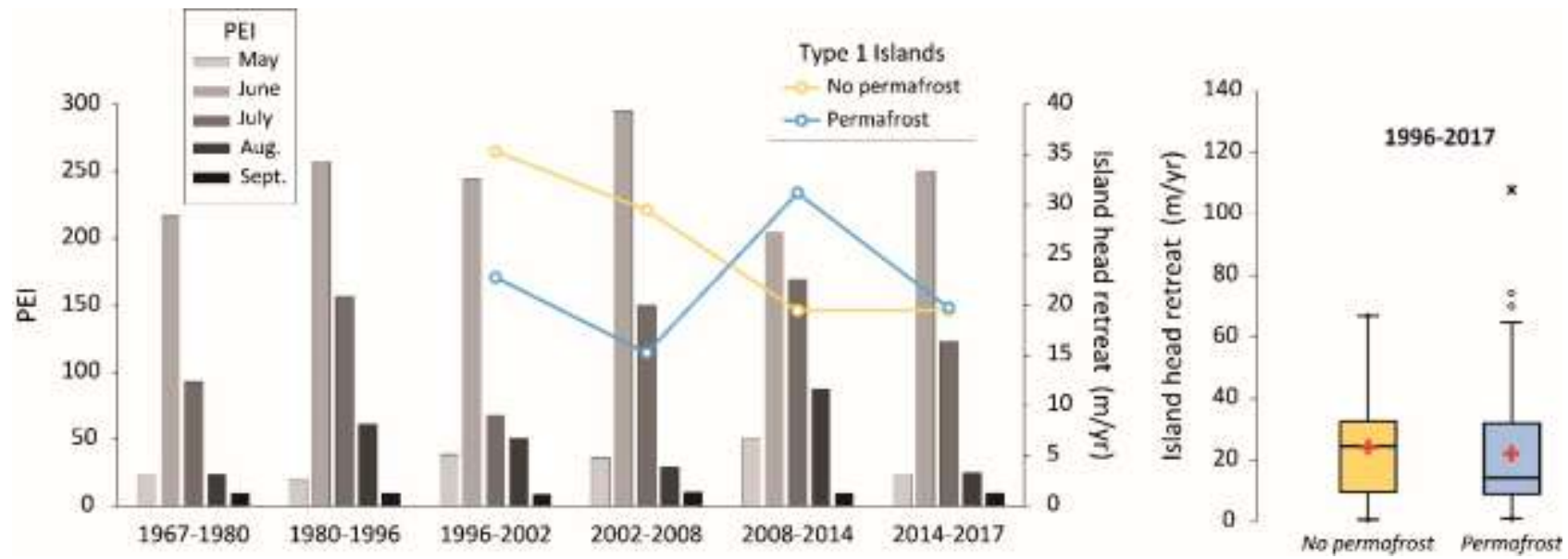

Figure 6. Potential Erosion Index and island head retreat $-\mathrm{A}$ : PEI monthly value $(\mathrm{PEI}=$ $\mathrm{T}^{\circ}$ water*ND20, with ND20: number of days with discharge exceeding the bar-full level); yellow line: bank erosion of young islands without permafrost (Type 1); blue line: bank erosion of old islands with permafrost (Type 1). B: Island head retreat for 1967 - 2017 (Type 1); left: islands without permafrost, right: islands with permafrost.

\subsection{Differential behavior of frozen and no-frozen islands}

On the basis of the field surveys conducted on numerous islands, we were able to determine that a mean of approximately 30 years separates young islands that are not perennially frozen and old islands with permafrost. Thus, to evaluate the effect of permafrost on the erosion rate, we distributed the islands in two groups (30 years old and above, and younger, Figure 6). The mean annual temperature of the permafrost at a depth of $3 \mathrm{~m}$ in the instrumented old islands was $-2^{\circ} \mathrm{C}$ (temperature ranged from $-16^{\circ} \mathrm{C}$ in the winter and $-0.6^{\circ} \mathrm{C}$ in the summer). The young islands only freeze seasonally with a temperature $\left(3 \mathrm{~m}\right.$ depth) ranging between $-7^{\circ} \mathrm{C}$ in the winter and $3^{\circ} \mathrm{C}$ in the summer. 
The calculation was applied from 1996 on (since the study began in 1967), to be sure to clearly distinguish between islands with and without permafrost. Since 1996, eroded surface was (in proportion) higher on young non-frozen islands as it ranged per year between 3.1 and $5.3 \%$ (the maximal value is recorded for the last period) of the island area. The islands with permafrost have lost $2.1-3.4 \%$ of the initial form per year. However, considering that the extent of the eroded area depends on the size and on the position of the island, the island head retreat (migration rate) is a better evidence of the potential effect of permafrost on erosion. We applied the calculation on Type 1 islands only, excluding large complex islands as they are formed by merging of islands and bars of various ages. Figure 6 highlights the difference in head erosion between old islands that have permafrost and young islands that only freeze in winter. For 1996-2008, islands that only froze in winter retreated faster than islands with permafrost, and the situation changed after 2008 when the mean erosion of the islands with permafrost suddenly increased. Median and extreme values of the two generations greatly differ (Figure 6B). For the whole period, the median value was lower for old islands. Nevertheless, the highest values are detected for the islands with permafrost (up to $70-100 \mathrm{~m}$ per year) and they were clearly correlated with the maximum PEI not only in May, but also in July and August, the warmest months (2008-2014, Figure 6A). This could likely express two different dynamics in terms of erosion.

\section{Discussion}

5.1. Interactions between hydrologic change, sediment and alluvial vegetation

In the case of the Lena River, various interacting factors that control island evolution can be discussed: water discharge and stream temperature, vegetation and permafrost. Concerning the Lena River, an increase in sediment input from the basin is unlikely to occur: the upper and middle basin, draining the Boreal forest, is almost a pristine region (in terms of land use) with a very low human density $\left(0.31\right.$ inhabitant per $\left.\mathrm{km}^{-2}\right)$.

The part played by water discharge on anabranching forms has already been demonstrated (Nanson and Knighton, 1996; Latrubesse, 2008; Hohensinner et al., 2004; Astrade, 2012; Raslan and Salam, 2015; Hudson, 2019). On the River Neris for example, Baubiniene et al. (2015) observed that the negative trend in the annual peak discharge and in the flood duration since the 1920s had its origins in reinforced in-channel deposition and, as a consequence, the rapid formation of islands. On the Lena River, at the beginning of the study period, the phase of island accretion could be related to a relatively long bar-full to bank-full water discharge (Table 3), and to the near-absence of large floods. Differently, the recent multiplication of islets and the associated strong erosion probably correspond 
to a period with long flooding duration accompanied by frequent large floods and numerous flood peaks (Table 3).

Water flow, sediment discharge and vegetation are jointly at work. The alluvial forest on the Lena islands is very homogeneous. Salix viminalis generally grows as a pioneer species on fresh bar deposits (i.e. the sandy deposits) and on the lowest part of islands, whereas S. trianda and $S$. dasycaldus are found on the finer deposits (fine sand, silt and loam) that overlay the sand. Grassland forms local patches on the upper topographical levels; it is mainly composed by Equisetum arvense - horsetail - and Bromopsis inermis - smooth brome. The duration of the bar-full stage in summer enables the willow to encroach on the barren bars and island margins. Even if it progressively decreases during the summer, the water level is sufficiently high to provide water to the propagules and young willows. The layering and suckering faculties of Salix also explain the rapid colonization of bars even in cold environments. The willow is a well-known engineer species that exerts a strong control over fluvial dynamics (Gurnell and Petts, 2002; Corenblit et al., 2007; Gurnell, 2014). It has also been demonstrated that long flooding duration explains enhanced vegetation activity, islands and floodplain receiving more nutrients (Marchetti et al., 2013). We can also suggest than the current warming favors the vegetation growth (Delbart et al., 2007). Thus, on the Lena River, the construction of islands likely depends on summer water discharge interacting with the growth of pioneer sequences. The efficiency of pioneer sequences on sediment trapping was recognized several decades ago (Nanson and Beach, 1977). The rapid growth of pioneer sequences on the islands in the Lena River (willow) in turn triggers the rapid vertical accretion (Costard et al., 2014).

However, the trees offer a weak resistance to the river outburst. During the strongest outbursts (2010 for example, Figure 2A), the floating ice and ice-jams can indeed destroy the alluvial vegetation on bars and island margins. During the rising limb, the fractured ice acts like a bulldozer that plans the bars and roots up the youngest trees. On island heads and banks, the ice-jams cut clean the willows (Pictures in Supplementary material). Our field surveys confirm that the drifting ice can completely erode the smallest islands. Furthermore, the willows do not efficiently protect banks from erosion, for several reasons. First, the roots are mainly developed in the active zone (the upper layer that thaws in the summer) that has a mean thickness about $0.5 \mathrm{~m}$ on the permafrost. Second, the islands are relatively high, they are perched about $3 \mathrm{~m}$ (up to $5-6 \mathrm{~m}$ for the oldest islands) above the low water stage.

Another important factor is the sedimentary texture and structure of islands that offer a low resistance to erosion. Bar and island sediment is homogeneous, as the river remobilizes the thick deposits of four main Pleistocene terraces, that have sand and loesslike silt mantles (Gautier and Costard, 2000; Tananaev, 2016). Bar - and consequently islands - are mainly composed of relatively well-sorted 
sand. The coarsest sand is deposited on the upstream part of bars ( $\mathrm{D}_{50}$ about $\left.300-350 \mu \mathrm{m}\right)$, the grainsize decreases towards the bar top and tail. The detailed analysis of undercut banks reveals that the islands are formed by very similar layers of medium and fine sand ( $\mathrm{D}_{50} 200-300 \mu \mathrm{m}$ ), very homogenous ( $85-90 \%$ of sand and $10-15 \%$ of clay fraction). The sand can be overlaid by fine overbank deposits that have a thickness ranging between $0.5-1 \mathrm{~m}\left(\mathrm{D}_{50} 18-30 \mu \mathrm{m}, 77-87 \%\right.$ of silt, $12-20 \%$ of clay and $1-3 \%$ of very fine sand). Very similar sedimentary facies and grain-size distribution have been described by Tananaev (2016) in two nearby banks where thermal erosion was precisely surveyed. Small inter-island channels are filled with an alternation of sandy loam and clay, often covered by thick accumulation black organic matter and woody debris.

\subsection{Global change, thermal erosion, and their effects on Lena River islands}

The precise analysis of head erosion of islands likely highlighted the increase in the erosion of the islands with permafrost (Figure 6). During the flood season, banks are subject to fluvial and thermal erosion (Soloviev, 1973; Jahn, 1975; Are, 1983; Gautier and Costard, 2000; Walker and Hudson, 2003; Costard et al., 2014; Kanevskiy et al., 2016; Tananaev, 2016; Chassiot et al., 2020). The duration of the discharge partly determines the efficiency of erosion: a continuously high and rapid flow progressively removes the loose material, thereby enabling direct contact between the water and the bank. The contact between the flow and the base of the bank often creates an erosional niche that subsequently triggers substantial collapses along the banks with permafrost (pictures in supplementary material). The niche formation is also worsened by the discontinuity between the sand and the silt. The island age plays also an important part, as older islands are higher; the higher the bank, the bigger the collapse. On the Lena, the extreme values of bank retreat measured on islands with permafrost can be explained by the collapse of the bank top above these thermo-erosional niches on old high islands, resulting in the removal of huge sections of the bank. This confirms the observations of Tananaev (2016), who shows that the erosion rate on the two surveyed sites is positively related with the height of the bank. Rapid bank retreat (up to $100 \mathrm{~m}$ per year) due to the combination of thermal erosion and collapses has also been documented on the Itkillik River in Alaska by Kanevskyi et al. (2016) between 1995 and 2010. However, the niche collapse blocks - that are still frozen - can also have the opposite effect by protecting the head of the island from erosion for a few hours/days before thawing, specifically when the water level is low. Because of the longer duration of discharge and because of the frequency of summer floods, the protective effect of the fallen blocks is certainly not as strong. The repeated flood peaks also reinforce the bank erosion (Figure 2B). Summer rainfall triggers floods that erode banks, but also favors bank instability by increasing the humidity in the active layer and thereby, enhancing heat transfer within the active layer. 
In the Lena delta, the erosion of a short section of a channel was precisely measured between 2013 and 2015 and its inter-annual variability appears to be significantly controlled by precipitation (Stettner et al., 2018).

The stream temperature also determines thermal erosion of the frozen banks (Costard et al., 2003). The stream temperature increases considerably from the beginning to the end of the flood season: the temperature is about $0.5^{\circ} \mathrm{C}$ in May and rises to $15^{\circ} \mathrm{C}$ in August. In laboratory experiments, a model of thermal erosion showed that water stream temperature has a stronger effect on thermal erosion than discharge (Costard et al., 2003; Dupeyrat et al., 2018, 2011). During the flood season, the relatively warm water melts the ice inside the porous structure of the sediments. The subsequent thawing of ice reduces the strength of the islands and increases erosion efficiency (Costard et al., 2014). The third main parameter is the ice content of the frozen riverbanks that also controls thermal erosion. In the Lena floodplain, permafrost persists in sandy deposits with $20-40 \%$ excess ice volume and in overbank silty deposits with even higher (40-80\%) excess ice volume (Costard et al., 2014). The increase in ice content has two opposing effects: sediment cohesion is reduced with an increase in ice content that promotes erosion, but the progression of the thaw front slows down with an increase in ice content (Dupeyrat et al., 2011). Thus, it is difficult to conclude on the relative effect of ice content on bank retreat.

However, our compared analysis of head erosion on islands with and without permafrost gives a first indication about the effect of permafrost on bank stability (Figure 6B). The median erosion of island (Type 1) head with permafrost was lower compared with non-frozen islands, suggesting that the majority of islands with permafrost was relatively more stable than non-frozen islands due to the latent heat needed to thaw the frozen bank (Costard et al., 2003). On the Lena River, both median and mean values have increased after 2008, becoming higher than the values measured on young islands: this evolution likely expresses the permafrost degradation and the strong response of the frozen banks to the current hydro-climatic change. Thus, the recent increase in bank instability of old islands is in agreement with the study on the Lena delta conducted by Lauzon et al. (2019), in which permafrost degradation and river-ice thickening resulted in more mobile channels. This point needs further investigation.

\subsection{Island model of the Lena River}

The diachronic study conducted on the middle Lena River is also a contribution to the fluvial island dynamics and more widely, to the anabranching fluvial systems. The Lena River has adopted an island pattern based on two island shapes that remobilize the sediment load at different time scales. 
The top of a mid-channel bar (Figure 7A in 1967, Island 104) can be colonized by the pioneer vegetation. If the very young island "survives" to a potential high flood, it remains in the center of the mainstream for more than 50 years: these islands $\left(1-10 \mathrm{~km}^{2}\right)$ continue to change by combining lateral and head erosion, downstream accretion and annexing of a close island (e.g. Island 222 on Figure 7B). Migrating rapidly, the islands become spindle-shaped. We observe for the last decade a rapid turn-over of these islands that are more rapidly formed and eroded.

The aggregation of several islands leads to a large composite (see Islands 103, 601 - 602 on Figure 7). These very large islands $\left(10-25 \mathrm{~km}^{2}\right)$ occupy $30-50 \%$ of the channel width. They are formed by downstream accretion, and sometimes, by merging lateral islands (Island 601 on Figure 7C). A bar can also be deposited upstream, in the bifurcation zone ("BZ", Islands 132, 128, 129 on Figure 7A). Two "blind channels" (according to Leli et al. 2018, "BC" on Figure 7A) where the vegetation grows rapidly, cause the lateral development and merging of the islands. The large islands are formed at multi-centennial time scales: the starting point of the largest islands is not visible on the 1967 Corona photographs, as they were already formed. They migrate downstream more slowly than the central islands, and they are subject to an increasing lateral erosion.

Consequently, fluvial islands on low-energy anabranching rivers form slowly, they depend on multidecadal morphogenesis, even centennial for the largest forms. On the Amazon River, the dating obtained within the scroll-bars are evidence for the multi-millennial construction of the islands (Rozo et al., 2012). Recently, Leli et al. (2020b) demonstrated the very long-term construction of islands on the upper Parana River, some of which are more than 8,000 years old.

Our construction model highlights similarities and variants of island dynamics in anabranching systems. On the Lena, island creation depends on a strong interaction with alluvial vegetation that stabilizes sand bars; no island was created by avulsion during the study period, which differs significantly from very active avulsive systems. Rozo et al. (2011) also reported that avulsion processes are uncommon in the Amazon River. Creation of islands by avulsion is apparently associated with higher energy systems, such as the Baghmati River (Jain and Sinha, 2004).

Both long and composite islands are similar to those described in the Parana River that flows through a sub-tropical region (Leli et al., 2018; 2020a), where both medium-sized relatively reshaped islands and large composite islands are also reported. The secondary laterally migrating channels seem to play an important but unequal role. On the Amazon River, the slow migration of slightly meandering secondary channels creates numerous islands with ox-bow lakes (Mertes et al., 1996; Rozo et al., 2012). On the basis of a physical model and on measurements made in the low Yangtse River, it has been demonstrated that the triangular planform of the islands is related with the proportion of water and sediment discharge flowing in the two branches surrounding the island (Liu et al., 2016). On the 
318 middle Lena River, abandoned meanders can be observed exclusively on the terraces, suggesting a 319 (non-dated) fluvial metamorphosis. The pattern in the Lena River does not correspond to the 320 migration of a meandering channel, as the present branches are straight. The system of synchronous 321 lateral migration of an island and its secondary channel was not detected in the Siberian river. 322 Therefore, we suggest that the low sinuosity and relative permanency of Lena channels are linked to 323 the low sediment load of the river. The Lena River is supposed to be the main sediment input to the 324 Laptev Sea (Alabyan et al., 1995). However, the sediment load is not precisely known (Antonov, 325 1960; Rivera et al., 2006). According to Gordeev (2006), the low suspended sediment input, being 326 about 20 million tons per year at Kyusyur, is mainly due to permafrost, low temperature and low 327 precipitation over the Lena basin. Even if the model developed by Gordeev (2006) predicts an 328 increase in sediment load positively correlated to the global warming, no precise data on sediment 329 load is available on the middle Lena River and no evidence has yet been found concerning a potential 330 increase in the sediment fluxes. 

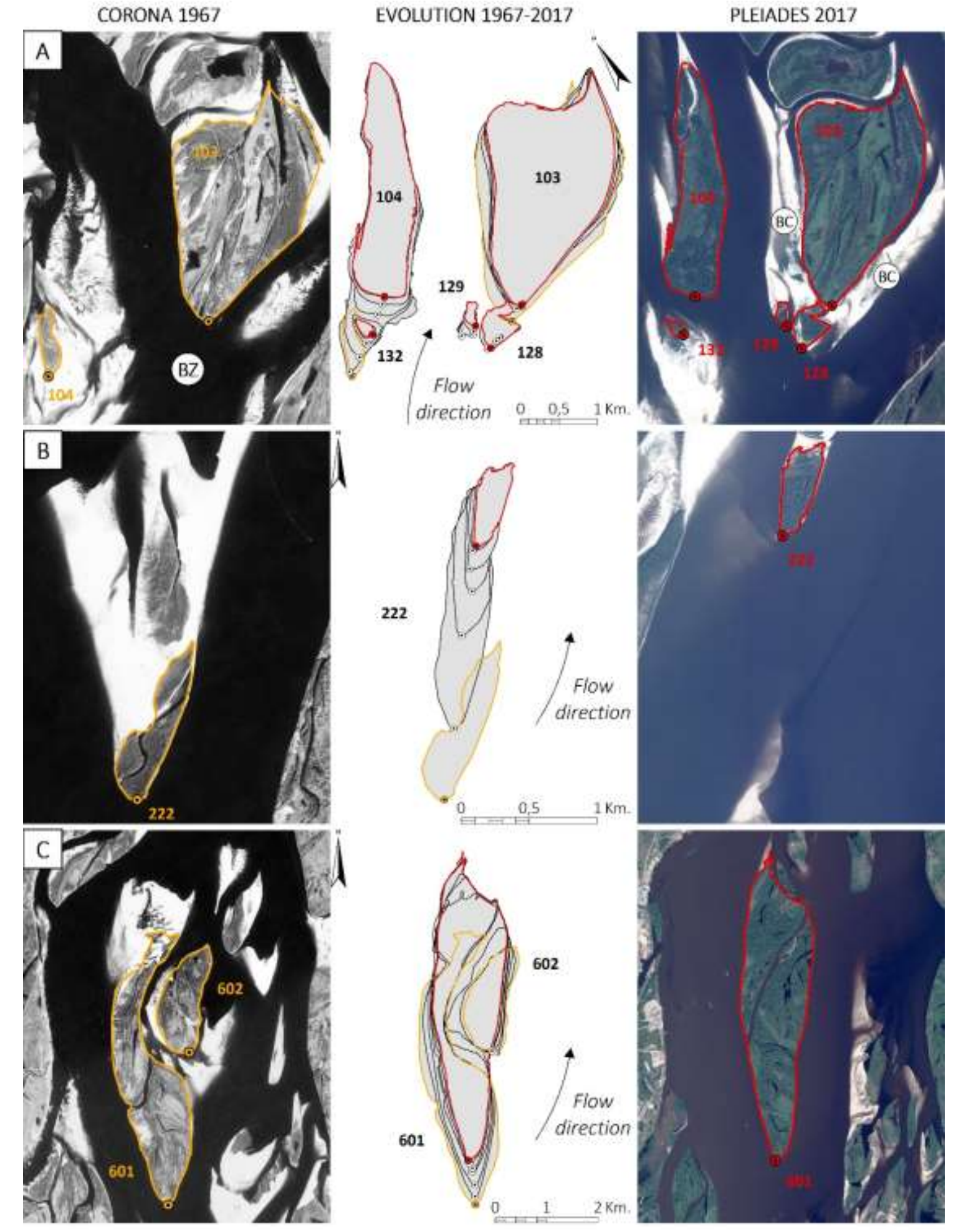

332 Figure 7. Main island patterns on the Lena River. BZ: bifurcation zone; BC: blind channel; number: 333 island ID. Left image: Corona picture (1967); right image: Pleiades 2017 (C) CNES, 2017, 334 Distribution Airbus DS, all rights reserved). 
The underpinning question of our study was to evaluate the island adjustment of a large periglacial river, the Lena, to climate change. The monitoring of the islands over a 50-year period, based on a coherent and reproducible method, highlights the rapid evolution of island dynamics over the recent period. The first period (1967 to 2002) was characterized by significant increase in the surface area of islands and by rapid migration of islands. At the beginning of the $21^{\text {st }}$ century, several morphodynamic parameters have changed: a strong decrease in accretion is noticed, numerous islets are formed and islands are subject to a stronger erosion. On the one hand, longer duration of bar-full water level in the summer coupled with the air and water warming probably enhances the development of pioneer sequences on bars. On the other hand, more frequent high floods coupled with repeated flood peaks in the summer are probably the main factors of the increasing erosion. Furthermore, the first signs of change detected to the islands with permafrost could indicate an increasing destabilization since 2008. Consequently, global warming and its hydrological consequences question the stability of the floodplain-permafrost and, via a feedback effect, the accelerating degradation of the permafrost accelerates the hydrological change. The sensitivity of the Lena River in Eastern Siberia is likely due to thawing of the permafrost. Thus, as large rivers are assumed to slowly react to climate change (Schumm, 1977; Vandenberghe, 2003), the recent changes to the Lena River prove that the global change deeply impacts periglacial rivers.

\section{Acknowledgments}

Assistance of the Melnikov Permafrost Institute of Yakutsk for field studies is gratefully acknowledged. Authors are funded by the GDR2012 Arctique: Enjeux pour l'Environnement et les Sociétés (CNRS INEE) and by the Agence Nationale de la Recherche (ANR) through the ANR ClimaFlu. This work was also supported by public funds received in the framework of GEOSUD, a project (ANR-10-EQPX-20) of the program "Investissements d'Avenir" managed by the French National Research Agency, for Spot and Pleiades images.

We also would like to thank the two anonymous reviewers and the Editor sincerely for their constructive comments and questions, which substantially improved the quality of our manuscript.

\section{References}

Alabyan, A.M., Chalov, R.S., Korotaev, V.N., Sodorchuk, A.U., Zaytsev, A.A., 1995. Natural and technologic water and sediment supply to the Laptev Sea. Report on Polar Research, 265-271. 
Are, F.E. 1983. Thermal abrasion on coasts, Proceedings, Fourth International Conference on Permafrost, Fairbanks, Alaska, National Academy Press, Washington D. C.; 24-28.

Ashworth, P.J., Lewin, J., 2012. How do big rivers come to be different? Earth-Science Rev. 114, 84-107. doi:10.1016/j.earscirev.2012.05.003

Baubiniene, A., Satkunas, J., Taminskas, J., 2015. Formation of fluvial islands and its determining factors, case study of the River Neris, the Baltic Sea basin. Geomorphology 231, 343-352. doi:10.1016/j.geomorph.2014.12.025

Bennett, K.E., Cannon, A.J., Hinzman, L., 2015. Historical trends and extremes in boreal Alaska river basins. J. Hydrol. 527, 590-607. doi:10.1016/j.jhydrol.2015.04.065

Berezovskaya, S., Yang, D., Hinzman, L., 2005. Long-term annual water balance analysis of the Lena River. Glob. Planet. Change 48, 84-95. doi:10.1016/j.gloplacha.2004.12.006

Brabets, T.P., Walvoord, M.A., 2009. Trends in streamflow in the Yukon River Basin from 1944 to 2005 and the influence of the Pacific Decadal Oscillation. J. Hydrol. 371, 108-119. doi:10.1016/j.jhydrol.2009.03.018

Carling, P., Jansen, J., Meshkova, L., 2014. Multichannel rivers: Their definition and classification. Earth Surf. Process. Landforms 39, 26-37. doi:10.1002/esp.3419

Chassiot, L., Lajeunesse, P., Bernier, J.F., 2020. Riverbank erosion in cold environments: Review and outlook. Earth-Science Rev. 207, 103231. doi:10.1016/j.earscirev.2020.103231

Corenblit, D., Tabacchi, E., Steiger, J., Gurnell A.M., 2007. Reciprocal interactions and adjustments between fluvial landforms and vegetation dynamics in river corridors: A review of complementary research. Earth-Science Review 84: 56-86.

Costard, F., Dupeyrat, L., Gautier, E., Carey-Gailhardis, E., 2003. Fluvial thermal erosion investigations along a rapidly eroding river bank: Application to the Lena River (Central Siberia). Earth Surf. Process. Landforms 28, 1349-1359. doi:10.1002/esp.592

Costard, F., Gautier, E., Brunstein, D., Hammadi, J., Fedorov, A., Yang, D., Dupeyrat, L., 2007. Impact of the global warming on the fluvial thermal erosion over the Lena River in Central Siberia. Geophys. Res. Lett. 34. doi:10.1029/2007GL030212

Costard, F., Gautier, E., Fedorov, A., Konstantinov, P., Dupeyrat, L., 2014. An assessment of the erosion potential of the fluvial thermal process during ice breakups of the Lena River (Siberia). Permafr. Periglac. Process. 25, 162-171. doi:10.1002/ppp.1812 
de Rham, L.P., Prowse, T.D., Bonsal, B.R., 2008. Temporal variations in river-ice break-up over the Mackenzie River Basin, Canada. J. Hydrol. 349, 441-454. doi:10.1016/j.jhydrol.2007.11.018

Delbart, N., Picard, G., Le Toan, T., Kergoat, L., Quegan, S., Woodward, I, Dye, D., Fedorova, V. 2008. Spring phenology in boreal Eurasia in a nearly century time-scale, Global Change Biology, 14, (3), 603-614.

Déry, S.J., Hernández-Henríquez, M.A., Burford, J.E., Wood, E.F., 2009. Observational evidence of an intensifying hydrological cycle in northern Canada. Geophys. Res. Lett. 36, 1-5. doi:10.1029/2009GL038852

Downs, P.W., Piégay, H., 2019. Catchment-scale cumulative impact of human activities on river channels in the late Anthropocene: implications, limitations, prospect. Geomorphology 338, 88104. doi:10.1016/j.geomorph.2019.03.021

Dupeyrat, L., Costard, F., Randriamazaoro, R., Gailhardis, E., Gautier, E., Fedorov, A., 2011. Effects of ice content on the thermal erosion of permafrost: Implications for coastal and fluvial erosion. Permafr. Periglac. Process. 22, 179-187. doi:10.1002/ppp.722

Dupeyrat, L., Hurault, B., Costard, F., Marmo, C., Gautier, E., 2018. Satellite image analysis and frozen cylinder experiments on thermal erosion of periglacial fluvial islands. Permafr. Periglac. Process. doi:10.1002/ppp.1973

Fedorov, A.N., Gavriliev, P.P., Konstantinov, P.Y., Hiyama, T., Iijima, Y., Iwahana, G., 2014a. Estimating the water balance of a thermokarst lake in the middle of the Lena River basin, eastern Siberia. Ecohydrology 7, 188-196. doi:10.1002/eco.1378

Fedorov, A.N., Ivanova, R.N., Park, H., Hiyama, T., Iijima, Y., 2014b. Recent air temperature changes in the permafrost landscapes of northeastern Eurasia. Polar Sci. 8, 114-128. doi:10.1016/j.polar.2014.02.001

Gautier, E., Costard, F., 2000. Anastomosing-fluvial systems in the periglacial zone: The Lena River and its main tributaries (Central Siberia) | Les systémes fluviaux à chenaux anastomosés en milieu périglaciaire: La Léna et ses principaux affluents (Sibérie centrale). Geogr. Phys. Quat. 54.

Gautier, E., Costard, F., Brunstein, D., Fedorov, A., Hammadi, J., Yang, D., 2008. Climate change and fluvial dynamics of the Lena river (Siberia). Proceedings of the $9^{\text {th }}$ International Permafrost Conference, Fairbanks Alaska, 493-498.

Gautier, Emmanuèle, Dépret, T., Costard, F., Virmoux, C., Fedorov, A., Grancher, D., Konstantinov, P., Brunstein, D., 2018. Going with the flow: Hydrologic response of middle Lena River 
(Siberia) to the climate variability and change. J. Hydrol. 557, 475-488. doi:10.1016/j.jhydrol.2017.12.034

Gordeev, V.V., 2006. Fluvial sediment flux to the Arctic Ocean. Geomorphology, 80, 94-104.

Goulding, H.L., Prowse, T.D., Bonsal, B., 2009. Hydroclimatic controls on the occurrence of breakup and ice-jam flooding in the Mackenzie Delta, NWT, Canada. J. Hydrol. 379, 251-267. doi:10.1016/j.jhydrol.2009.10.006

Gurnell, A.M., 2014. Plants as river system engineers. Earth Surface Processes and Landforms 39, 424. DOI: 10.1002:esp.3397

Gurnell, A.M., Petts, G.E., 2002. Island-dominated landscapes of large floodplain rivers, a European perspective. Freshw. Biol. 47, 581-600. doi:10.1046/j.1365-2427.2002.00923.x

Hohensinner, S., Habersack, H., Jungwirth, M., Zauner, G., 2004. Reconstruction of the characteristics of a natural alluvial river-floodplain system and hydromorphological changes following human modifications: The Danube River (1812-1991). River Res. Appl. 20, 25-41. doi:10.1002/rra.719

Huang, H.Q., Nanson, G.C., 2007. Why some alluvial rivers develop an anabranching pattern. Water Resour. Res. 43, 1-12. doi:10.1029/2006WR005223

Hudson, P.F., van der Hout, E., Verdaasdonk, M., 2019. (Re)Development of fluvial islands along the lower Mississippi River over five decades, 1965-2015. Geomorphology 331, 78-91. doi:10.1016/j.geomorph.2018.11.005

Huisink, M., De Moor, J.J.W., Kasse, C., Virtanen, T., 2002. Factors influencing periglacial fluvial morphology in the northern European Russian tundra and taiga. Earth Surf. Process. Landforms 27, 1223-1235. doi:10.1002/esp.422

Iijima, Y., Fedorov, A.N., Park, H., Suzuki, K., Yabuki, H., Maximov, T.C., Ohata, T., 2010. Abrupt Increases in Soil Temperatures following Increased Precipitation in a Permafrost Region , Central Lena River Basin , Russia 41, 30-41. doi:10.1002/ppp.662

Iijima, Y., Nakamura, T., Park, H., Tachibana, Y., Fedorov, A.N., 2016. Enhancement of Arctic storm activity in relation to permafrost degradation in eastern Siberia. Int. J. Climatol. 2007. doi:10.1002/joc.4629

IPCC, 2019. Special Report on the Ocean and Cryosphere in a Changing Climate. Chap. 3. Polar regions.

Jahn, A. 1975. Problems of the periglacial zone, Washington D.C., Warzawa, 223 p. 
Jain, V., Sinha, R., 2004. Fluvial dynamics of an anabranching river system in Himalayan foreland basin, Baghmati river, north Bihar plains, India. Geomorphology 60, 147-170. doi:10.1016/j.geomorph.2003.07.008

Kanevskiy, M., Shur, Y., Strauss, J., Jorgenson, T., Fortier, D., Stephani, E., Vasiliev, A., 2016. Patterns and rates of riverbank erosion involving ice-rich permafrost (yedoma) in northern Alaska. Geomorphology 253, 370-384. doi:10.1016/j.geomorph.2015.10.023

Klavins, M., Briede, A., Rodinov, V., 2009. Long term changes in ice and discharge regime of rivers in the Baltic region in relation to climatic variability. Clim. Change 95, 485-498. doi:10.1007/s10584-009-9567-5

Kleinhans, M.G., de Haas, T., Lavooi, E., Makaske, B., 2012. Evaluating competing hypotheses for the origin and dynamics of river anastomosis. Earth Surf. Process. Landforms 37, 1337-1351. doi:10.1002/esp.3282

Kleinhans, M.G., Ferguson, R.I., Lane, S.N., Hardy, R.J., 2013. Splitting rivers at their seams: Bifurcations and avulsion. Earth Surf. Process. Landforms 38, 47-61. doi:10.1002/esp.3268

Konstantinov, PY, Fedorov, AN, Machimura, T, Iwahana, G, Yabuki, H, Iijima, Y, Costard, F. 2011. Use of automated recorders (data loggers) in permafrost temperature monitoring. Kriosphera Zemli; 1: 23-32.

Lang, M., Ouarda, T.B.M.J., Bobee, B., 1999. Towards operational guidelines for over-threshold modelling. J. Hydrol. 225, 103-117.

Latrubesse, E.M., 2008. Patterns of anabranching channels: the ultimate end-member adjustment of mega-rivers. Geomorphology 101, 130-145. DOI: 10.1016/j.geomorpho.2008.05.035

Lauzon, R., Piliouras, A., Rowland, J.C., 2019. Ice and Permafrost Effects on Delta Morphology and Channel Dynamics. Geophys. Res. Lett. 46, 6574-6582. doi:10.1029/2019GL082792

Leli, I.T., Stevaux, J.C., Assine, M.L., 2018. Genesis and sedimentary record of blind channel and islands of the anabranching river: An evolution model. Geomorphology 302, 35-45. doi:10.1016/j.geomorph.2017.05.001

Leli, I.T., Stevaux, J.C., Assine, M.L., 2020a. Origin, evolution, and sedimentary records of islands in large anabranching tropical rivers: The case of the Upper Paraná River, Brazil. Geomorphology 358, 107118. doi:10.1016/j.geomorph.2020.107118

Leli, I.T., Stevaux, J.C., Assine, M.L., 2020b. Architecture, sedimentary facies and chronology of a composite island: a model from the upper Parana River, Brazil. Geomorphology 372, 107-457. doi:10.1016/j.geomorph.2020.107457 
Liu, X., Huang, H.Q., Nanson, G.C., 2016. The morphometric variation of islands in the middle and lower Yangtze River: A variational analytical explanation. Geomorphology 261, 273-281. doi:10.1016/j.geomorph.2016.03.004

Lopatin, G.V., 1952. Nanosy rek SSSR. Moscou, Geographiz, Mem. Soc. Fed. Geogr., vol.14, 336 p.

Marchetti, Z., Latrubesse E.M., Pereira, M.S., Ramonell, C.G., 2013. Vegetation and its relationship with geomorphologic units in the Parana River floodplain, Argentina. Journal of South America Earth Sciences, 46: 122-136.

Matti, B., Dahlke, H.E., Lyon, S.W., 2016. On the variability of cold region flooding. J. Hydrol. 534, 669-679. doi:10.1016/j.jhydrol.2016.01.055

Mertes, L.A.K., Dunne, T., Martinelli, L.A., 1996. Channel-floodplain geomorphology along the Solimões-Amazon River, Brazil. Bull. Geol. Soc. Am. 108, 1089-1107. doi:10.1130/00167606(1996)108<1089:CFGATS>2.3.CO;2

Morón, S., Edmonds, D.A., Amos, K., 2017. The role of floodplain width and alluvial bar growth as a precursor for the formation of anabranching rivers. Geomorphology 278, 78-90. doi:10.1016/j.geomorph.2016.10.026

Morse, P.D., Wolfe, S.A., 2017. Long-Term River Icing Dynamics in Discontinuous Permafrost, Subarctic Canadian Shield. Permafr. Periglac. Process. 28, 580-586. doi:10.1002/ppp.1907

Nanson, G.C., Beach, H.F., 1977. Forest succession and sedimentation on a meandering-river floodplain, northeast British Columbia, Canada. Journal of Biogeography 4, 229-251.

Nanson, G.C., David Knighton, A., 1996. Anabranching rivers: Their cause, character and classification. Earth Surf. Process. Landforms 21, 217-239. doi:10.1002/(SICI)10969837(199603)21:3<217::AID-ESP611>3.0.CO;2-U

Nanson, G.C., Huang, H.Q., 2017. Self-adjustment in rivers: Evidence for least action as the primary control of alluvial-channel form and process. Earth Surf. Process. Landforms 42, 575-594. doi:10.1002/esp.3999

Park, H., Yoshikawa, Y., Oshima, K., Kim, Y., Ngo-Duc, T., Kimball, J.S., Yang, D., 2016. Quantification of warming climate-induced changes in terrestrial Arctic river ice thickness and phenology. J. Clim. 29, 1733-1754. doi:10.1175/JCLI-D-15-0569.1

Pavelsky, T.M., Smith, L.C., 2004. Spatial and temporal patterns in Arctic river ice breakup observed with MODIS and AVHRR time series. Remote Sens. Environ. 93, 328-338. doi:10.1016/j.rse.2004.07.018 
Payne, C., Panda, S., Prakash, A., 2018. Remote sensing of river erosion on the Colville river, North Slope Alaska. Remote Sens. 10. doi:10.3390/rs 10030397

Peterson, B.J., Peterson, B.J., Holmes, R.M., Mcclelland, J.W., Vo, C.J., Lammers, R.B., Shiklomanov, A.I., Shiklomanov, I.A., Rahmstorf, S., 2002. Increasing River Discharge to the Arctic Ocean. Science (80-. ). 298, 2171-2173. doi:10.1126/science.1077445

Prowse, T., Alfredsen, K., Beltaos, S., Bonsal, B., Duguay, C., Korhola, A., McNamara, J., Pienitz, R., Vincent, W.F., Vuglinsky, V., Weyhenmeyer, G.A., 2011. Past and future changes in arctic lake and river ice. Ambio 40, 53-62. doi:10.1007/s13280-011-0216-7

Raslan, Y., Radwa, S., 2015. Development of Nile River islands between old Assam dam and new Esna barrages. Water Science, 1110-4229. DOI/ 10.1016/j.wsj.2015.03.003

Richards, K., 1982. Rivers: Form and Process in Alluvial Channels. Methuen, 358 p.

Rivera, J., Karabanov, E.B., Williams, D.F., Buchinskyi, V., Kuzmin M., 2006. Lena River discharge events in sediments of Laptev Sea, Russian Arctic. Estuarine, Coastal and Shelf Science 66: 185196. doi:10.1016/j.ecss.2005.08.009

Rood, S.B., Kaluthota, S., Philipsen, L.J., Rood, N.J., Zanewich, K.P., 2017. Increasing discharge from the Mackenzie River system to the Arctic Ocean. Hydrol. Process. 31, 150-160. doi:10.1002/hyp.10986

Rozo, M.G., Nogueira, A.C.R., Truckenbrodt, W., 2012. The anastomosing pattern and the extensively distributed scroll bars in the middle Amazon River. Earth Surf. Process. Landforms 37, 1471-1488. doi:10.1002/esp.3249

Schumm, S.A., 1977. The fluvial system. Wiley, 338 p.

Schumm, SA. 1979. Geomorphic thresholds: the concept and its applications. Transactions of the Institute of British Geographers 54:485-515.

Serreze, M.C., Bromwich, D.H., Clark, M.P., Etringer, A.J., Zhang, T., Lammers, R., 2002. Largescale hydro-climatology of the terrestrial Arctic drainage system. J. Geophys. Res. 108, 8160. doi:10.1029/2001JD000919

Shiklomanov, I.A., Shiklomanov, A.A.I., Lammers R.B., Peterson B.J. and Vorosmarty C.J., 2000. The dynamics of river water inflow to the Arctic Ocean. In The fresh water budget of The Arctic Ocean, Proceeding of the NATO Advanced Research Workshop, Tallin, Estonia, 27 April - 1 May 1998, Kluwer Acad.: 281-296.

Shiklomanov, A.I., Lammers, R.B., Rawlins, M.A., Smith, L.C., Pavelsky, T.M., 2007. Temporal and 
spatial variations in maximum river discharge from a new Russian data set. J. Geophys. Res. Biogeosciences 112, 1-14. doi:10.1029/2006JG000352

Shiklomanov, A.I., Lammers, R.B., 2009. Record Russian river discharge in 2007 and the limits of analysis. Environ. Res. Lett. 112, 1-14. doi:10.1029/2006JG000352

Shiklomanov, A.I., Lammers, R.B., 2014. River ice responses to a warming Arctic - Recent evidence from Russian rivers. Environ. Res. Lett. 9. doi:10.1088/1748-9326/9/3/035008

Shpakova, R., Kusatov, K., Mustafin, S., Trifonov, A., 2019. Changes in the nature of long-term fluctuations of water flow in the subarctic region of Yakutia: A global warming perspective. Geosci. 9. doi:10.3390/geosciences9070287

Soloviev, P.A. 1973. Thermokarst phenomena and landforms due to frost heaving in Central Yakutia. Biul. Peryglac. 23: 135-155.

Starkel, L., Gregory, K.J., Thornes, J.B (eds) 1991. Temperate Palaeohydrology. Fluvial Processes in the Temperate Zone during the last 15000 Years. Wiley, 548 pp.

Stettner, S., Beamish, A.E., Bartsch, A., Heim, B., Grosse, G., Roth, A., Lantuit, H., 2018. Monitoring inter- and intra-seasonal dynamics of rapidly degrading ice-rich permafrost riverbanks in the Lena delta with TerraSAR-X time series. Remote Sensing, 10/51, doi:10.3390/rs10010051

Tananaev, N.I., 2016. Hydrological and sedimentary controls over fluvial thermal erosion, the Lena River, central Yakutia. Geomorphology 253, 524-533. doi:10.1016/j.geomorph.2015.11.009

Tei, S., Morozumi, T., Nagai, S., Takano, S., Sugimoto, A., Shingubara, R., Fan, R., Fedorov, A., Gavrilyeva, T., Tananaev, N., Maximov, T., 2020. An extreme flood caused by a heavy snowfall over the Indigirka River basin in Northeastern Siberia. Hydrol. Process. 34, 522-537. doi:10.1002/hyp.13601

Turcotte, B., Morse, B., 2013. A global river ice classification model. J. Hydrol. 507, 134-148. doi:10.1016/j.jhydrol.2013.10.032

Vandenberghe, J., 2003. Climate forcing of fluvial system development: An evolution of ideas. Quat. Sci. Rev. 22, 2053-2060. doi:10.1016/S0277-3791(03)00213-0

Walker, H.J., Hudson, P.F., 2003. Hydrologic and geomorphic processes in the Colville River delta, Alaska. Geomorphology 56, 291-303. doi:10.1016/S0169-555X(03)00157-0

Walvoord, M.A., Kurylyk, B.L., 2016. Hydrologic impacts of thawing permafrost - a review. Vadose Zo. J. 15, 1-20. doi:10.2136/vzj2016.01.0010

Yang, D., Kane, D.L., Hinzman, L.D., Zhang, X., Zhang, T., Ye, H., 2002. Siberian Lena River 
hydrologic regime and recent change. J. Geophys. Res. Atmos. 107, 1-10. 589 doi:10.1029/2002JD002542

590 Yang, D., Shi, X., Marsh, P., 2015. Variability and extreme of Mackenzie River daily discharge 591 during 1973-2011. Quat. Int. 380-381, 159-168. doi:10.1016/j.quaint.2014.09.023

592 Ye, B., Yang, D., Zhang, Z., Kane, D.L., 2009. Variation of hydrological regime with permafrost 593 coverage over Lena Basin in Siberia. J. Geophys. Res. Atmos. 114. doi:10.1029/2008JD010537 594 Zhang, X., He, J., Zhang, J., Polyakov, I., Gerdes, R., Inoue, J., Wu, P., 2012. Enhanced poleward 595 moisture transport and amplified northern high-latitude wetting trend. Nat. Clim. Chang. 3, 47596 51. doi:10.1038/nclimate 1631 